\title{
Design and Experimental Evaluation of a Peptide Antagonist against Amyloid $\beta(1-42)$ Interactions with Calmodulin and Calbindin-D28k
}

\author{
Jairo Salazar $^{1,2}$, Joana Poejo ${ }^{1,3}\left(\mathbb{D}\right.$, Ana M. Mata ${ }^{1,3} \mathbb{( D}$, Alejandro K. Samhan-Arias ${ }^{4,5}$ \\ and Carlos Gutierrez-Merino 1,3,*(D)
}

check for

updates

Citation: Salazar, J.; Poejo, J.; Mata,

A.M.; Samhan-Arias, A.K.;

Gutierrez-Merino, C. Design and

Experimental Evaluation of a Peptide

Antagonist against Amyloid $\beta(1-42)$

Interactions with Calmodulin and

Calbindin-D28k. Int. J. Mol. Sci. 2022,

23, 2289. https://doi.org/10.3390/

ijms23042289

Academic Editor: Claudiu

T. Supuran

Received: 20 January 2022

Accepted: 12 February 2022

Published: 18 February 2022

Publisher's Note: MDPI stays neutral with regard to jurisdictional claims in published maps and institutional affiliations.

Copyright: (C) 2022 by the authors. Licensee MDPI, Basel, Switzerland. This article is an open access article distributed under the terms and conditions of the Creative Commons Attribution (CC BY) license (https:// creativecommons.org/licenses/by/ $4.0 /)$.
1 Instituto de Biomarcadores de Patologías Moleculares, Universidad de Extremadura, 06006 Badajoz, Spain; jairochemsalazar@gmail.com (J.S.); joanapoejo86@gmail.com (J.P.); anam@unex.es (A.M.M.)

2 Departamento de Química, Universidad Nacional Autónoma de Nicaragua-León, León 21000, Nicaragua

3 Departamento de Bioquímica y Biología Molecular y Genética, Facultad de Ciencias, Universidad de Extremadura, 06006 Badajoz, Spain

4 Department of Biochemistry, Faculty of Medicine, Universidad Autónoma de Madrid (UAM), Arzobispo Morcillo, 4, 28029 Madrid, Spain; alejandro.samhan@uam.es

5 Instituto de Investigaciones Biomédicas 'Alberto Sols' (CSIC-UAM), Arturo Duperier, 4, 28029 Madrid, Spain

* Correspondence: carlosgm@unex.es

\begin{abstract}
Amyloid $\beta_{1-42}(\mathrm{~A} \beta(1-42))$ oligomers have been linked to the pathogenesis of Alzheimer's disease (AD). Intracellular calcium $\left(\mathrm{Ca}^{2+}\right)$ homeostasis dysregulation with subsequent alterations of neuronal excitability has been proposed to mediate $\mathrm{A} \beta$ neurotoxicity in $\mathrm{AD}$. The $\mathrm{Ca}^{2+}$ binding proteins calmodulin (CaM) and calbindin-D28k, whose expression levels are lowered in human AD brains, have relevant roles in neuronal survival and activity. In previous works, we have shown that CaM has a high affinity for $A \beta(1-42)$ oligomers and extensively binds internalized $A \beta(1-42)$ in neurons. In this work, we have designed a hydrophobic peptide of 10 amino acid residues: VFAFAMAFML (amidatedC-terminus amino acid) mimicking the interacting domain of CaM with $\mathrm{A} \beta(1-42)$, using a combined strategy based on the experimental results obtained for $A \beta(1-42)$ binding to CaM and in silico docking analysis. The increase in the fluorescence intensity of $\mathrm{A} \beta(1-42) \mathrm{HiLyte}^{\mathrm{TM}}$-Fluor555 has been used to monitor the kinetics of complex formation with CaM and with calbindin-D28k. The complexation between nanomolar concentrations of $A \beta(1-42)$ and calbindin-D28k is also a novel finding reported in this work. We found that the synthetic peptide VFAFAMAFML (amidated-C-terminus amino acid) is a potent inhibitor of the formation of $A \beta(1-42)$ :CaM and of $A \beta(1-42)$ :calbindin-D28k complexes.
\end{abstract}

Keywords: Amyloid $\beta$; calmodulin; calbindin-D28k; antagonist peptide; Alzheimer's disease; fluorescence; docking

\section{Introduction}

Amyloid $\beta_{1-42}(A \beta(1-42))$ oligomers have been linked to Alzheimer's disease (AD) pathogenesis and suggested to be the cause of neuronal damage [1-3]. Also, it has been shown that neuronal uptake and accumulation of $A \beta(1-42)$ aggregates correlate with metabolic inhibition [4]. Indeed, intraneuronal amyloid $\beta(A \beta)$ accumulation precedes the appearance of amyloid plaques or tangles in transgenic mice models of AD [5-8]. In addition, the microinjection of $A \beta(1-42)$ or cDNA encoding $A \beta(1-42)$ has been shown to be neurotoxic to cultures of human neurons [9]. The dysregulation of intracellular calcium $\left(\mathrm{Ca}^{2+}\right)$ homeostasis with subsequent alterations in neuronal excitability has been proposed to mediate $\mathrm{A} \beta$ neurotoxicity in $\mathrm{AD}$ [10-12]. Moreover, many studies have shown that $A \beta(1-42)$ oligomers modulate the activity of systems that play a major role in the control of neuronal intracellular $\mathrm{Ca}^{2+}$ homeostasis, reviewed in [13].

The $\mathrm{Ca}^{2+}$-binding protein calmodulin $(\mathrm{CaM})$ is present at high concentrations in neurons and reaches micromolar concentrations in cortical and hippocampal neurons, 
which have a high expression of this protein [14,15]. These neurons are in the brain areas that are highly prone to neurodegeneration in AD. In a previous work, we have shown that $\mathrm{CaM}$ binds to $\mathrm{A} \beta(1-42)$ oligomers and $\mathrm{A} \beta(25-35)$ peptide, with a dissociation constant of the $\mathrm{A} \beta:\left(\mathrm{Ca}^{2+}\right)_{4}-\mathrm{CaM}$ complex close to $1 \mathrm{nM}$ [16]. Therefore, CaM has a high capacity to buffer the intracellular concentrations of these highly neurotoxic $\mathrm{A} \beta$ peptides. More recently, we have shown that CaM binds most of the $\mathrm{A} \beta(1-42)$ internalized in cerebellar granule neurons in culture after $2 \mathrm{~h}$ incubation with $2 \mu \mathrm{M}$ of $\mathrm{A} \beta(1-42)$ oligomers added to the extracellular medium [17]. Dissociation constants of approximately $1 \mathrm{nM}$ have been reported only for the complexes between $\mathrm{A} \beta$ peptides with two other proteins expressed in brain neurons, namely, cellular prion protein [18] and glycogen synthase kinase $3 \alpha$ [19]. Since the concentration of CaM in neurons is orders of magnitude higher than that of these proteins, we can conclude that CaM can act as a major neuronal sink for neurotoxic intracellular $\mathrm{A} \beta$ peptides. As $\mathrm{CaM}$ has a major regulatory role in neuronal metabolism, excitability, and intracellular calcium signaling $[12,13,20]$, the possibility that $A \beta(1-42): C a M$ complexes could also function as intracellular transducers for the focalized actions of $A \beta$ peptides emerges from our previous works.

Calbindin-D28k is also a major $\mathrm{Ca}^{2+}$ binding protein that is highly expressed in the brain [21] and plays a major role in the control of the resting cytosolic $\mathrm{Ca}^{2+}$ concentration in hippocampal neurons. In fact, the inhibition of calbindin-D28k expression elicits a prolonged increase in intraneuronal $\mathrm{Ca}^{2+}$ concentration after $\mathrm{N}$-methyl-D-aspartate or potassium stimulation of hippocampal slices [22]. It should be noted that calbindin-D28k protein levels are markedly reduced in brain samples from human AD and rodent models of $\mathrm{AD}$ [23]. The calbindin-D28k-expressing cells in the brains of AD patients have been shown to be more resistant to degeneration [24]. In glial and neuronal cells, the overexpression of calbindin-D28k has been shown to inhibit the apoptosis induced by $\mathrm{A} \beta$ and the mutant presenilin-1 detected in AD [25,26]. In addition, the calbindin-D28k knock-out of transgenic mice with 5 familial AD mutations (5XFAD;Tg) aggravates AD pathogenesis, suggesting that calbindin-D28k has a critical role in AD pathogenesis [27].

The use of CaM knock-out animal models or CaM si-RNA in cultured neurons is strongly hampered by the high relevance of these proteins to brain development and normal neuronal function, respectively. This severely limits our knowledge of the relative contribution of the many different putative molecular mechanisms underlying intracellular $\mathrm{Ca}^{2+}$ dysregulation by internalized $\mathrm{A} \beta(1-42)$. Since there is a wide range of intracellular signaling pathways modulated by $\mathrm{CaM}$ in neurons, there is a need for alternative strategies to experimentally evaluate the effects of $\mathrm{A} \beta(1-42)$ :CaM complexation in neuronal activity and also in neuronal plasticity and survival. On the other hand, CaM is a small and water-soluble protein whose high-resolution, three-dimensional structure is available in the UniProt Protein Data Bank, as well as that of $A \beta(1-42)$ monomer. This fact allows for the performance of docking simulations between them, opening the possibility of designing high affinity antagonist polypeptides against this interaction. Indeed, it is known that several endogenous neuropeptides can antagonize the actions of $A \beta$, both in animal models [28-30] and in cell cultures [31,32]. Furthermore, in our previous study of $\mathrm{A} \beta(1-42)$ :CaM complexation, we concluded that the $\mathrm{A} \beta(25-35)$ peptide interaction with $\mathrm{CaM}$ is largely dominated by hydrophobic interactions between the uncharged amino acids of both the peptide and CaM [16]. Due to this, it is likely that the amino acid sequence of $\mathrm{A} \beta(1-42)$ that is directly involved in the formation of the $\mathrm{A} \beta(1-42)$ :CaM complex could also be implicated in the complexation of $A \beta(1-42)$ with other neuronal proteins, although with lower affinity. While $A \beta(1-42)$ :CaM complex formation may account for, at least in part, the large range of subcellular signaling pathways reported to be altered by intracellular and extracellular $A \beta(1-42)$, this is a point that still deserves to be experimentally assessed.

On these grounds, the main goal of this work has been to design a peptide that can antagonize the formation of the $\mathrm{A} \beta(1-42)$ :CaM complex and experimentally evaluate its efficiency to prevent the complexation of $A \beta(1-42)$ with CaM and with calbindin-D28k. To this end, we have set up a fluorescence assay to monitor the formation of the complex 
of $\mathrm{A} \beta(1-42)$ with purified recombinant human CaM. Using this approach, we show that $\mathrm{A} \beta(1-42)$ also binds to calbindin-D28k, although with a slightly lower affinity than to CaM. Then, we have used a docking strategy to simulate the most probable model structures of the $A \beta(1-42)$ :CaM complex that meet the experimental requirements derived from our previous work [16] and to design synthetic peptides that can antagonize the formation of complexes between $\mathrm{A} \beta(1-42): C a M$ and $A \beta(1-42)$ :calbindin-D28k.

\section{Results}

\subsection{Interaction between $A \beta(1-42) H_{i L y t e}{ }^{T M}-$ Fluor555 and Calmodulin (CaM)}

In a previous work [16] we found that titration of the fluorescent $A \beta(1-42) \mathrm{HiLyte}^{\mathrm{TM}}$ Fluor555 with nanomolar CaM concentrations enhances the fluorescence intensity. The results of the Figure $1 \mathrm{~A}$ show that the addition of $5 \mathrm{nM}$ of $\mathrm{CaM}$ to a $10 \mathrm{nM}$ of $\mathrm{A} \beta(1-42)$ HiLyte $^{\mathrm{TM}}$-Fluor555 solution elicits a kinetics of increase in the fluorescence intensity of the HiLyte $^{\mathrm{TM}}$-Fluor555 dye of 20-25\%, in good agreement with the results reported in [16]. This allows for the monitoring of the kinetics of interaction between both molecules and points out that the microenvironment of the dye is significantly altered upon formation of the $\mathrm{A} \beta(1-42)$ HiLyte $^{\mathrm{TM}}$-Fluor555:CaM complex. Also, it is to be noted that this complex formation does not produce a significant shift in the emission spectra of $A \beta(1-42) \mathrm{HiLyte}^{\mathrm{TM}}$ Fluor555 (data not shown). The increase in fluorescence as a function of time after the addition of CaM follows first-order kinetics (Figure $1 \mathrm{~B})$, with a rate constant $\left(\mathrm{k}_{\mathrm{on}}\right)$ of $(4.0 \pm 0.3) \cdot 10^{-3} \mathrm{~s}^{-1}$, i.e., with a half-time of $173 \pm 10 \mathrm{~s}$.

Next, we studied this kinetic process with $10 \mathrm{nM}$ of $\mathrm{A} \beta(1-42) \mathrm{HiLyte}^{\mathrm{TM}}$-Fluor555 at different concentrations of $\mathrm{CaM}$, i.e., by varying the molar ratio of $\mathrm{A} \beta(1-42)$ : $\mathrm{CaM}$ (Figure $1 \mathrm{C}$ ). These results revealed that the maximum fluorescence change was achieved when CaM concentration increased from 2.5 to $5 \mathrm{nM}$, and it is not significantly different between 5 and $10 \mathrm{nM}$ of CaM. It is noteworthy that at $5 \mathrm{nM}$ of CaM the molar ratio is $2: 1$, and in a previous work, we concluded that CaM binds $\mathrm{A} \beta(1-42)$ dimers [16]. Thus, the results shown in the Figure $1 \mathrm{C}$ lend further support to this hypothesis, because $A \beta(1-42)$ is largely in a dimeric state in our experimental conditions, as indicated in the Materials and Methods section. However, with a 1:1 molar ratio of $\mathrm{A} \beta(1-42): \mathrm{CaM}$, i.e., $10 \mathrm{nM}$ of CaM and $10 \mathrm{nM}$ of $\mathrm{A} \beta(1-42)$, the rate constant of the kinetic process increases about 4-fold, up to $(18 \pm 4) \cdot 10^{-3} \mathrm{~s}^{-1}$ (half-time $38 \pm 7 \mathrm{~s}$ ), suggesting that a second CaM molecule can also bind to the $\mathrm{A} \beta(1-42)_{2}:$ CaM complex, leading to $\mathrm{A} \beta(1-42)_{2}: \mathrm{CaM}_{2}$ complexes.

The previous kinetic studies allowed us to obtain the rate of formation of the $A \beta(1-42)$ HiLyte $^{\text {TM}}$-Fluor555:CaM complex, and also pointed out a high affinity of CaM for A $\beta(1-42)$, resulting in extensive complexation in the nanomolar concentration range of both partners. In order to evaluate the dissociation constant of the A $\beta(1-42)$ HiLyte $^{\text {TM}}$-Fluor555:CaM complex, we have measured the kinetics of reversion of the increase in fluorescence upon addition of 100 of $\mathrm{nM}$ of non-labelled $\mathrm{A} \beta(1-42)$ after the completion of the kinetics of $\mathrm{A} \beta(1-$ 42) HiLyte ${ }^{\mathrm{TM}}$-Fluor555:CaM complex formation under the same experimental conditions (Figure 1D). The decrease in the fluorescence monitors the kinetics of exchange of $A \beta(1-42)$ HiLyte $^{\mathrm{TM}}$-Fluor555 by non-labelled $\mathrm{A} \beta(1-42)$. It can be seen that this is a much slower kinetic process, since the time needed for the decay to half the increase of fluorescence is $900 \pm 50 \mathrm{~s}$, and we have calculated a rate constant of the exchange of $\mathrm{A} \beta(1-42) \mathrm{HiLyte}^{\mathrm{TM}}$ Fluor555 by non-labelled $A \beta(1-42)\left(\mathrm{k}_{\mathrm{off}}\right)$ of $(7.7 \pm 0.9) \cdot 10^{-4} \mathrm{~s}^{-1}$. Thus, our results led to a value of about 5 for the ratio between the average rate constant of the rate-limiting steps of complex formation and dissociation $\left(\mathrm{k}_{\mathrm{on}} / \mathrm{k}_{\mathrm{off}}\right)$. This pointed out that at nanomolar concentrations of $\mathrm{A} \beta(1-42)$ and $\mathrm{CaM}$, the equilibrium is largely displaced towards the $\mathrm{A} \beta(1-42)$ : CaM complex formation. 
A

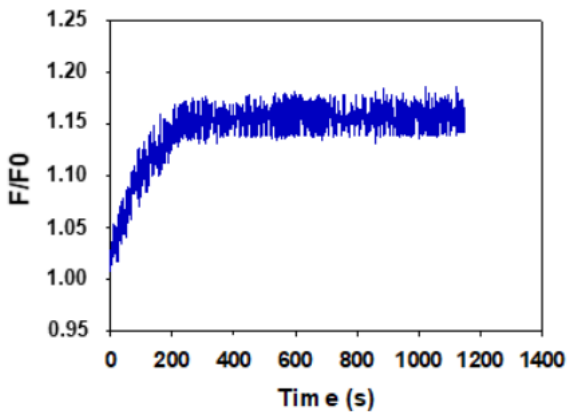

C

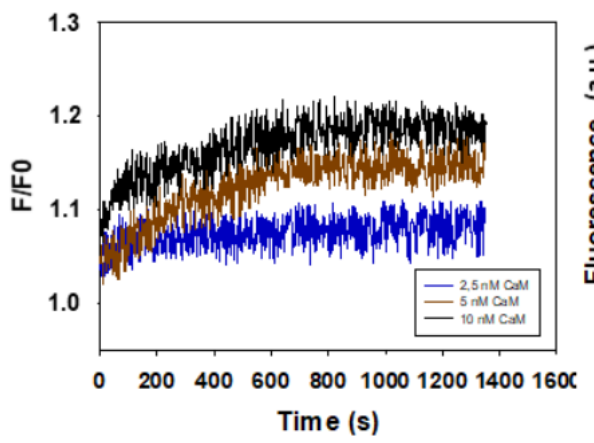

B

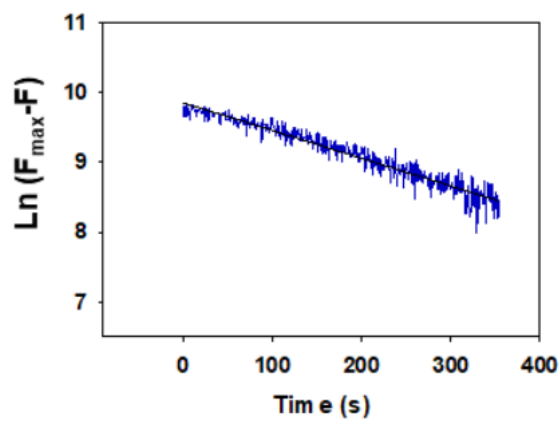

D

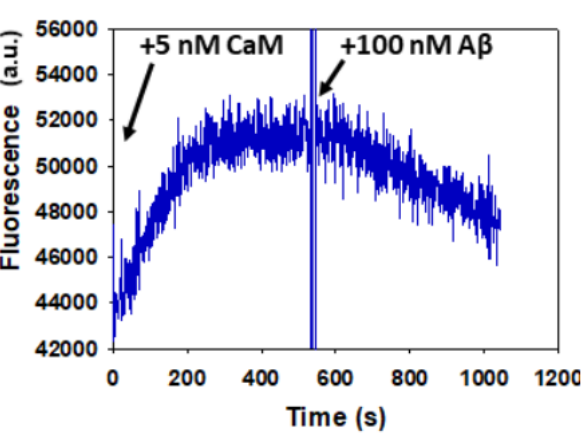

Figure 1. The kinetics of complex formation between $A \beta(1-42)$ and $C a M$ monitored by the increase in the fluorescence of $\mathrm{A} \beta(1-42) \mathrm{HiLyte}^{\mathrm{TM}}$-Fluor555. (A) A representative kinetic recording of the increase in the fluorescence intensity of $10 \mathrm{nM}$ of $\mathrm{A} \beta(1-42) \mathrm{HiLyte}^{\mathrm{TM}}$-Fluor555 after the addition of $5 \mathrm{nM}$ of CaM. (B) The increase in fluorescence of $\mathrm{A} \beta(1-42) \mathrm{HiLyte}^{\mathrm{TM}}$-Fluor555 has been fit to a first-order kinetic process. $\mathrm{F}_{\max }$ is the maximum fluorescence intensity at the completion of the kinetic process. The black continuous line is the linear least-squares fit of the data of the panel A to the equation: $y=9.845-0.00396 \times\left(R^{2}=0.922\right)$. (C) The dependence of the kinetics of increase in fluorescence intensity of $10 \mathrm{nM}$ of $\mathrm{A} \beta(1-42) \mathrm{HiLyte}^{\mathrm{TM}}$-Fluor555 upon the following concentrations of CaM: $2.5 \mathrm{nM}$ (blue), $5 \mathrm{nM}$ (brown) and $10 \mathrm{nM}$ (black). (D) A reversion of the increase in fluorescence of $\mathrm{A} \beta(1-42)$ HiLyte $^{\mathrm{TM}}$-Fluor555 elicited by $5 \mathrm{nM}$ of CaM by the addition of $100 \mathrm{nM}$ of $\mathrm{A} \beta(1-42)$ at the point indicated by an arrow. The fluorescence measurements have been performed as indicated in the Materials and Methods, and a.u. means fluorescence units given by the fluorimeter readings.

\subsection{Docking between $A \beta(1-42)$ and $C a M$ and the Criteria to Select the Most Probable in Silico} Structural Models of the A $\beta(1-42)$ :CaM Complex

Docking between $\mathrm{A} \beta(1-42)$ and $\mathrm{CaM}$ has been performed following the methodology indicated in the Materials and Methods section. First, we obtained the PDB files of the 10 most probable structures after Gibbs free energy minimization $(\Delta \mathrm{G})$ given by the ClusPro server for the $A \beta(1-42)$ PDB ID: 1 IYT and $1 Z 0 Q$ files. Taking into account the experimental results obtained in our previous work on $A \beta(1-42)$ :CaM complex formation [16], we considered acceptable only the simulations for the $A \beta(1-42): C a M$ complex that presented strong hydrophobic interactions between the amino acids residues of the peptide in the 25-35 segment. Also, our previous work showed that $A \beta(1-42): C a M$ complexation does not alter $\mathrm{Ca}^{2+}$ binding to $\mathrm{CaM}[16]$, excluding that $\mathrm{A} \beta(1-42)$ binds to the $\mathrm{Ca}^{2+}$-binding domains of CaM. The application of these criteria reduced the number of most probable model structures for the complex formation between $\mathrm{A} \beta(1-42)$ and CaM to 4 . Then, we selected two highly ranked hydrophobic-favored models, one for each $A \beta(1-42)$ PDB ID file, applying the criteria of the lowest $\Delta G$ values among the models that showed extensive 
overlap with the CaM domain interacting with the $A \beta(25-35)$ peptide shown in Figure 4 of ref. [16]. The interacting interface of the two selected models was analyzed using PDBePISA (Protein Interfaces, Surfaces, and Assemblies). We named our models as the Structures 1 and 2 shown in the Figures 2 and 3 , respectively. The $\Delta \mathrm{G}$ values obtained for structures 1 and 2 were -17 and $-15 \mathrm{kcal} / \mathrm{mol}$, which are consistent with the low dissociation constant of the $A \beta(1-42): C a M$ complex reported in our previous experimental work [16]. The in silico analysis of the interacting interface is summarized in Table 1, which shows the most likely amino acid residues of $\mathrm{A} \beta(1-42)$ and $\mathrm{CaM}$ involved in the interactions established for both model structures of the $A \beta(1-42)$ :CaM complex. To be conservative, we have included in these lists only those amino acid residues of $\mathrm{A} \beta(1-42)$ and $\mathrm{CaM}$ with BSA/ASA $\geq 0.5$, i.e., well above the threshold recommended value of 0.15 .

A

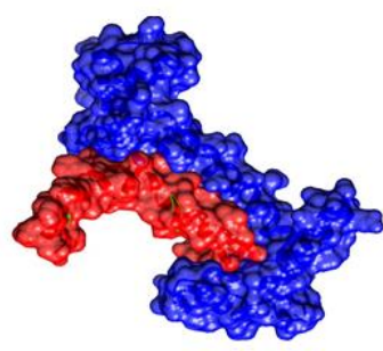

B

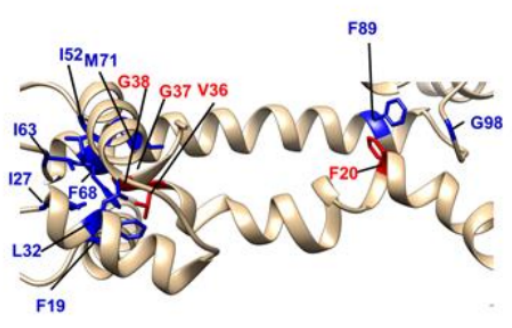

C

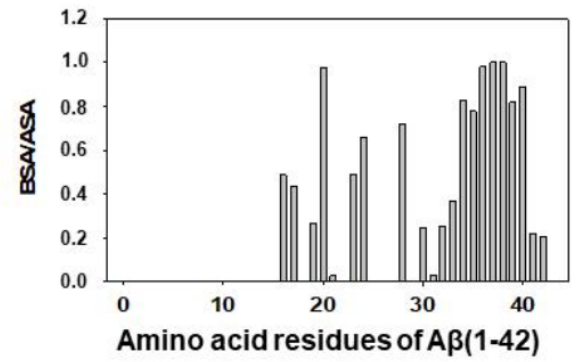

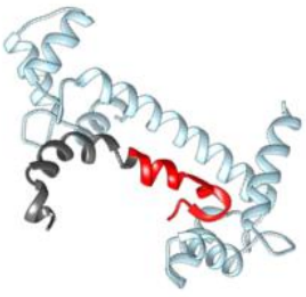
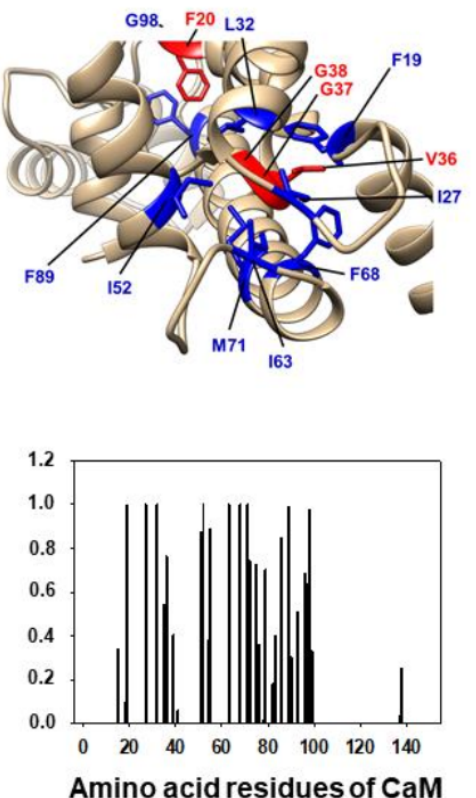

Figure 2. The selected in silico model structure 1 of the complex $A \beta(1-42)$ :CaM obtained using the PDB ID files: $1 Z 0 \mathrm{Q}$ for $\mathrm{A} \beta(1-42)$ and $1 \mathrm{CLL}$ for $\mathrm{Ca}^{2+}$-saturated CaM. Docking was performed as indicated in the Materials and Methods section. (A) The space-filled and peptide and protein backbone images of the complex. $\mathrm{A} \beta(1-42)$ is stained in red and CaM is stained in blue in the spacefilled image. The protein backbone of $\mathrm{CaM}$ is stained in light blue, the $24-42$ amino acid residues of $\mathrm{A} \beta(1-42)$ are stained in red, and the rest of the $A \beta(1-42)$ is stained in dark grey. (B) The structural details of the $A \beta(1-42): C a M$ interface of in silico model structure 1 : a side view on the left and a front view on the right. The CaM amino acid residues (colored in blue) more strongly interact with the 24-42 amino acid residues of $A \beta(1-42)$ (colored in red). (C) Graphic charts of the BSA/ASA values obtained for the amino acids residues of $A \beta(1-42)$ and $C a M$ in the in silico model structure 1 of the A $\beta(1-42)$ :CaM complex. 
A
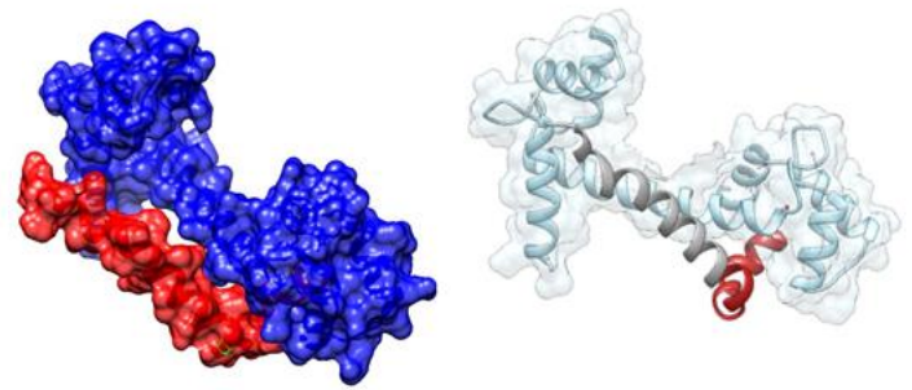

B

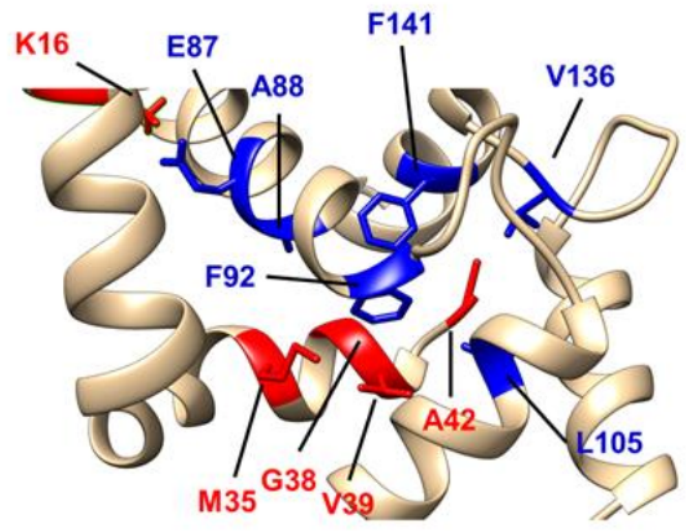

C

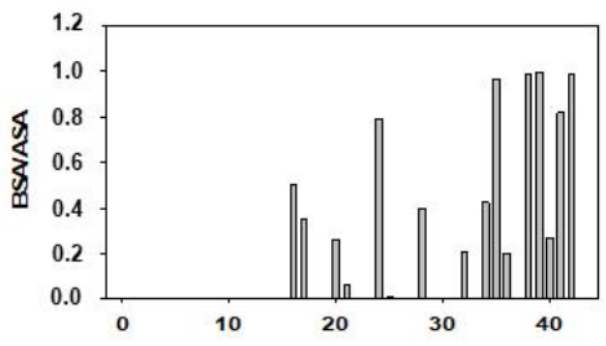

Amino acid residues of $A \beta(1-42)$

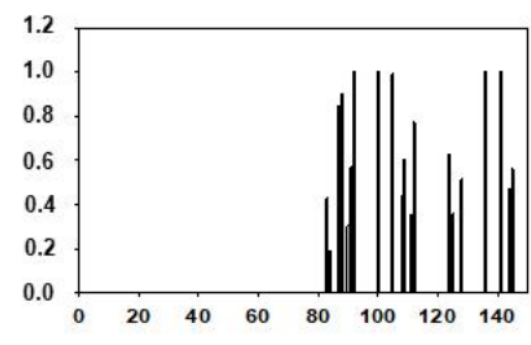

Amino acid residues of CaM

Figure 3. The selected in silico model structure 2 of the complex $A \beta(1-42)$ :CaM obtained using the PDB ID files: 1IYT for A $\beta(1-42)$ and 1CLL for $\mathrm{Ca}^{2+}$-saturated CaM. Docking was performed as indicated in the Materials and Methods section. (A) The space-filled and peptide and protein backbone images of the complex. $\mathrm{A} \beta(1-42)$ is stained in red and CaM is stained in blue in the spacefilled image. The protein backbone of CaM is stained in light blue, the $24-42$ amino acid residues of $A \beta(1-42)$ are stained in red, and the rest of the $A \beta(1-42)$ is stained in dark grey. (B) The structural details of the $A \beta(1-42)$ :CaM interface of in silico model structure 2 . The CaM amino acid residues (colored in blue) more strongly interact with the 24-42 amino acid residues of $A \beta(1-42)$ (colored in red). (C) Graphic charts of the BSA/ASA values obtained for the amino acids residues of A $\beta(1-42)$ and $\mathrm{CaM}$ in the in silico model structure 2 of the $\mathrm{A} \beta(1-42): \mathrm{CaM}$ complex. 
Table 1. A list of the strongly interacting amino acid residues of $A \beta(1-42)$ and $C a M$ in structures 1 and 2 yielded by docking simulations for the 1:1 A $\beta(1-42)$ :CaM complex. The amino acid residues of both $\mathrm{A} \beta(1-42)$ and CaM are listed from high to low values of the parameter BSA/ASA (values in parenthesis), obtained from the interface analysis with PDBePISA software. Only amino acids with BSA/ASA values $\geq 0.5$ are listed.

\begin{tabular}{ccc}
\hline & Aß(1-42) Amino Acid Residues & CaM Amino Acid Residues \\
\hline & & Ile27 (1.0), Leu32 (1.0), Ile52 (1.0), \\
& Gly37 (1.0), Gly38 (1.0), Val36 & Ile63 (1.0), Phe68 (1.0), Met71 (1.0), \\
Phe19 (0.99), Phe89 (0.99), Gly98 \\
Model structure 1 & (0.98), Phe20 (0.97), Val40 (0.89), & $(0.98)$, Val55 (0.89), Met51 (0.88), \\
& Leu34 (0.83), Val39 (0.82), Met35 & Arg86 (0.85), Met36 (0.76), Met72 \\
& $($ (0.77), Lys28 (0.72), Val24 (0.66) & $(0.74)$, Lys75 (0.73), Thr79 (0.70), \\
& & Gly96 (0.68), Asn97 (0.64) \\
\hline & & Val136 (1.0), Phe141 (1.0), Phe92 \\
Model structure 2 & (0.98), Met35 (0.96), Ile41 (0.82), & Glu87 (0.85), Leu112 (0.77), Met124 \\
& Val24 (0.79), Lys16 (0.5) & $(0.63)$, Met109 (0.61), Val91 (0.57), \\
& & Met145 (0.56), Ala128 (0.52) \\
\hline
\end{tabular}

2.3. Design of an Antagonist Peptide for the Formation of the A $\beta(1-42): C a M$ Complex and Its Experimental Evaluation

In order to design a peptide antagonist for the complex formation between $A \beta(1-42)$ and $\mathrm{CaM}$, we first identified the amino acid residues of CaM directly interacting with the amino acid residues of the 24-42 peptide domain of $A \beta(1-42)$ in the previously selected docking simulations (structures 1 and 2), see the detail of the structures 1 and 2 shown in the Figures $2 \mathrm{~B}$ and $3 \mathrm{~B}$. The data shown in the Table 1 highlight the most relevant amino acids residues of $A \beta(1-42)$ and $C a M$ found in the analysis of the interface using the simulated model structures of the $A \beta(1-42): C a M$ complex in silico. We choose the structure 1 of the $A \beta(1-42)$ and $\mathrm{CaM}$ as the template structure for the design of the peptide, because the prediction shows more amino acid residues in the 24-42 domain of A $\beta(1-42)$ strongly interacting with $\mathrm{CaM}$, as pointed out by the average higher values of the parameter BSA/ASA obtained from the interface analysis with PDBePISA software (Table 1), and, also, have a more favorable $\Delta G$ value. Next, we calculated the separation distance between the CaM amino acid residues participating in these pairs in the three-dimensional CaM structure. Thereafter, using standard amino acid residues volume size, we introduced nonpolar amino acid residues to yield a separation between amino acid residues mimicking their separation in the three-dimensional CaM structure. This operational protocol led us to the following ten amino acid residues peptide (from N-terminus to C-terminus): VFAFAMAFML (amidated-C-terminus amino acid) as a putative peptide antagonist for the formation of the $A \beta(1-42)$ :CaM complex.

The synthetic peptide VFAFAMAFML (amidated-C-terminus amino acid) has been tested for its ability to antagonize $\mathrm{A} \beta(1-42)$ :CaM complex formation using $\mathrm{A} \beta(1-42)$ HiLyte $^{\mathrm{TM}}$-Fluor555. The results (Figure 4) show that only submicromolar concentrations of this peptide are needed to inhibit the kinetic of fluorescence increase that monitors the interaction between $10 \mathrm{nM}$ A $\beta(1-42)$ HiLyte $^{\mathrm{TM}}$-Fluor555 and $5 \mathrm{nM}$ CaM. Indeed, $1 \mu \mathrm{M}$ of the peptide VFAFAMAFML (amidated-C-terminus amino acid) completely blocks the kinetics of fluorescence increase. An IC50 value of $75 \pm 10 \mathrm{nM}$ can be calculated for this peptide from these results, as indicated in the legend of the Figure $4 \mathrm{~B}$. 

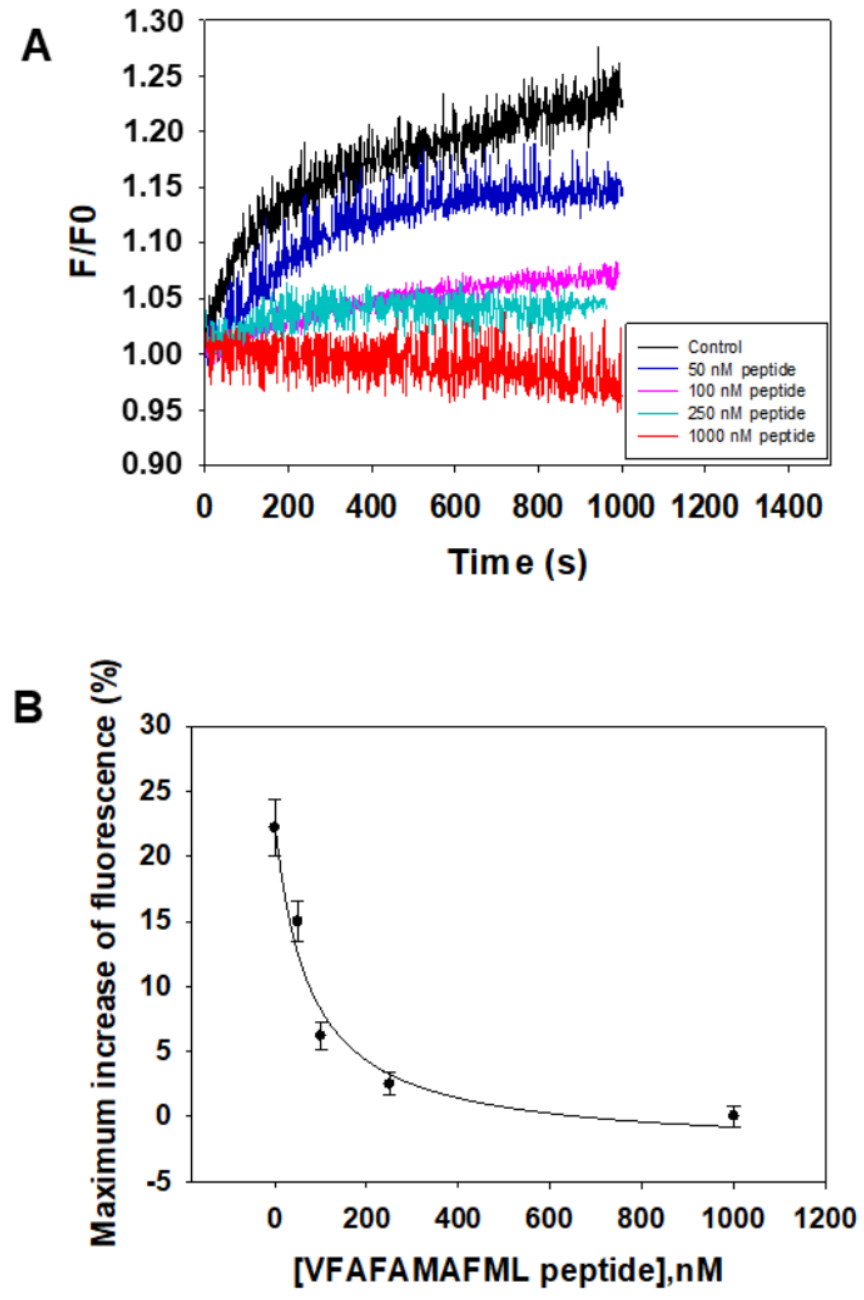

Figure 4. The synthetic peptide VFAFAMAFML (amidated-C-terminus amino acid) antagonizes A $\beta(1-42)$ :CaM complex formation. (A) Effect of increasing concentrations of this synthetic peptide on the kinetics of increase of the fluorescence intensity of $10 \mathrm{nM} \mathrm{A} \beta(1-42)$ HiLyte $^{\mathrm{TM}}$-Fluor555 after the addition of $5 \mathrm{nM}$ CaM. Titration with the synthetic peptide and fluorescence measurements have been performed as indicated in the Materials and Methods. The kinetics of fluorescence were recorded in the presence of the following concentrations of the peptide VFAFAMAFML (amidated-C-terminus amino acid): 0 (black), $50 \mathrm{nM}$ (dark blue), $100 \mathrm{nM}$ (pink), $250 \mathrm{nM}$ (cyan) and $1000 \mathrm{nM}$ (red). (B) Plot of the dependence of the maximum increase of fluorescence recorded $1000 \mathrm{~s}$ after the addition of CaM as a function of the concentrations of the peptide VFAFAMAFML (amidated-C-terminus amino acid). The data shown are the average (black-filled circles) \pm S.E. (error bars) of the results obtained in triplicate measurements. The continuous line is the non-linear square fit of the data to the hyperbolic equation for a one site binding drug-inhibitory effect: $\mathrm{Y}=\mathrm{Y} 0-[\mathrm{Qmax} \times \mathrm{x} /(\mathrm{IC} 50+\mathrm{x})]$, where $\mathrm{Y} 0$ is the maximum fluorescence increase in the absence of the peptide, Qmax is the maximum quenching of the increase of fluorescence at saturation of the peptide and IC50 is the concentration of the peptide that reduces to half the maximum increase of fluorescence. The data fitting gave the following results: $\mathrm{R}^{2}=0.966, \mathrm{Y} 0=22 \%, \mathrm{Qmax}=22 \%$ and IC50 $=75 \pm 10 \mathrm{nM}$.

\subsection{Interaction between $A \beta(1-42)$ HiLyte ${ }^{T M}-$ Fluor555 and Calbindin-D28k}

The increase of fluorescence intensity of the HiLyte ${ }^{\mathrm{TM}}-$ Fluor555 dye after the addition of $5 \mathrm{nM}$ calbindin-D28k to a $10 \mathrm{nM} \mathrm{A} \beta(1-42)$ HiLyte $^{\mathrm{TM}}$-Fluor555 solution is shown in the Figure 5A. Our results show that the change in fluorescent intensity is even higher than that found with CaM (see Figure 1A). Thus, the results of the fluorescence kinetics which monitors the interaction between calbindin-D28k point out that the microenvironment of the dye is more significantly altered upon formation of the complex of $\mathrm{A} \beta(1-42)$ HiLyte $^{\mathrm{TM}}$-Fluor555 
with calbindin-D28k than with CaM. Also, it should be highlighted that this complex formation do not produce a significant shift of the wavelength of the major emission band of the spectra of $\mathrm{A} \beta(1-42) \mathrm{HiLyte}^{\mathrm{TM}}$-Fluor555 (data not shown). Noteworthy, the kinetics of increase of fluorescence observed after addition of calbindin-D28k to a $10 \mathrm{nM} \mathrm{A} \beta(1-42)$ HiLyte $^{\mathrm{TM}}$-Fluor 555 solution has an initial lag phase of about $1 \mathrm{~min}$, which was not observed in the kinetics after the addition of CaM. This result suggests an initial conformational shift in the $A \beta(1-42)$ :calbindin-D28k that ensues a tighter interaction between both molecules. Consistent with this, the time needed to reach $50 \%$ of the maximum increase of the fluorescence of $\mathrm{A} \beta(1-42)$ HiLyte $^{\mathrm{TM}}$-Fluor555 is higher than that found with CaM, namely, $250 \pm 10 \mathrm{~s}$ for calbindin-D28k versus $173 \pm 10 \mathrm{~s}$ for CaM (Figures 1A and $5 \mathrm{~A}$ ).

A

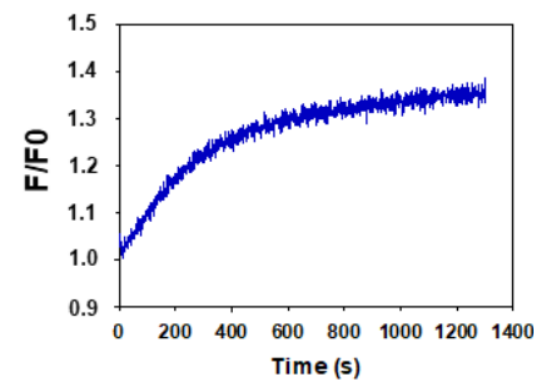

C

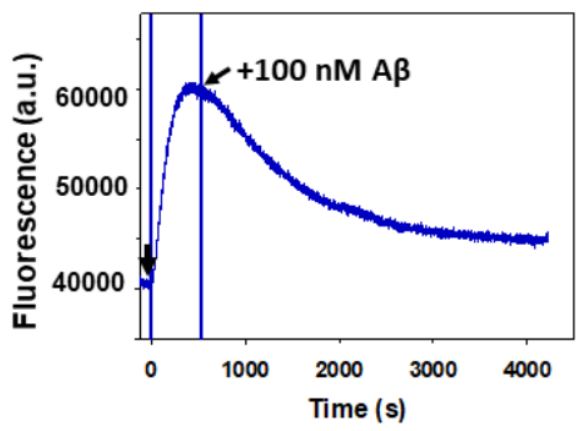

B

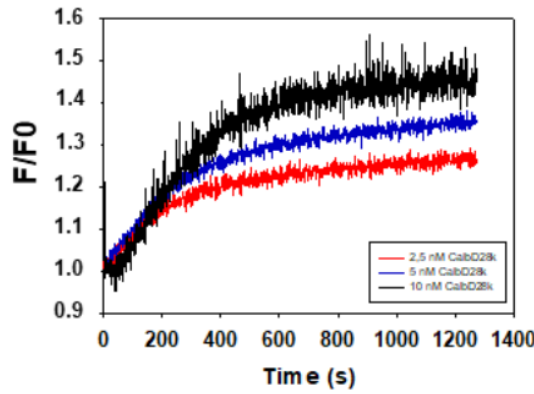

D

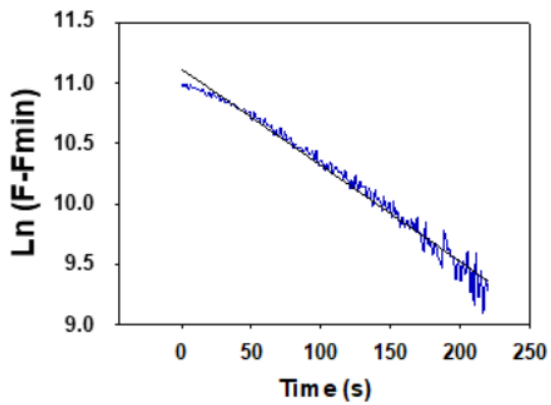

Figure 5. Kinetics of complex formation between $A \beta(1-42)$ and calbindin-D28k monitored by the increase of the fluorescence of $\mathrm{A} \beta(1-42) \mathrm{HiLyte}^{\mathrm{TM}}$-Fluor555. (A) Representative kinetic recording of the increase of the fluorescence intensity of $10 \mathrm{nM} \mathrm{A} \beta(1-42)$ HiLyte $^{\mathrm{TM}}$-Fluor555 after the addition of $5 \mathrm{nM}$ calbindin-D28k. (B) Dependence of the kinetics of increase of fluorescence intensity of $10 \mathrm{nM}$ $\mathrm{A} \beta(1-42)$ HiLyte $^{\mathrm{TM}}$-Fluor555 upon the concentration of calbindin-D20k: $2.5 \mathrm{nM}$ (red), $5 \mathrm{nM}$ (blue) and $10 \mathrm{nM}$ (black). (C) The increase of fluorescence of $\mathrm{A} \beta(1-42)$ HiLyte $^{\mathrm{TM}}$-Fluor555 after addition of $5 \mathrm{nM}$ calbindin-D28k (first arrow) is reversed by the addition of $100 \mathrm{nM} \mathrm{A} \beta(1-42)$ at the point indicated by the second arrow. (D) The decay of the fluorescence of $A \beta(1-42)$ HiLyte ${ }^{\text {TM }}$-Fluor555 after the addition of $100 \mathrm{nM} \mathrm{A} \beta(1-42)$ follows a first-order kinetic process with an initial lag phase of around $60 \mathrm{~s}$. Fmin is the minimum fluorescence intensity at the completion of the kinetic process. The black continuous line is the linear least-squares fit of the data of the panel $\mathrm{C}$ to the equation: $y=11.12-0.007998 x\left(R^{2}=0.982\right)$. Fluorescence measurements have been performed as indicated in the Materials and Methods, and a.u. means fluorescence units given by the fluorimeter readings.

Figure $5 \mathrm{~B}$ shows the dependence of this kinetic process upon the addition of different concentrations of calbindin-D28k. These results revealed that the maximum change of fluorescence increases when calbindin-D28k concentration increases from 2.5 up to $10 \mathrm{nM}$. At $10 \mathrm{nM}$ calbindin-D28k concentration the molar ratio $\mathrm{A} \beta(1-42)$ : calbindin-D28k is 1:1. 
Since A $\beta(1-42)$ is largely in dimeric state in our experimental conditions, as indicated in the Materials and Methods section, these results lend support to the hypothesis that complexes of $(\mathrm{A} \beta(1-42))_{2}$ : (calbindin-D28k $)_{2}$ are being formed.

The previous kinetics indicated a high affinity of calbindin-D28k for $A \beta(1-42)$ resulting in extensive complexation in the nanomolar concentration range of both partners. This was confirmed by the reversion of the increase of fluorescence elicited by $5 \mathrm{nM}$ calbindin-D28k upon addition of $100 \mathrm{nM}$ of non-labelled $\mathrm{A} \beta(1-42)$ after completion of the kinetics of $\mathrm{A} \beta(1-42)$ HiLyte $^{\mathrm{TM}}$-Fluor555: calbindin-D28k complex formation (Figure $\left.5 \mathrm{C}\right)$. The decrease of the fluorescence monitors the kinetics of exchange of $\mathrm{A} \beta(1-42) \mathrm{HiLyte}^{\mathrm{TM}}-\mathrm{Fluor} 555$ by non-labelled $A \beta(1-42)$, and from these results the rate of dissociation of $A \beta(1-42)$ HiLyte $^{\text {TM}}$-Fluor555:calbindin-D28k complexes can be calculated. It can be seen that this is a slower kinetic process with a short lag time of 1-2 $\mathrm{min}$, pointing out that a conformational relaxation of the complex is needed before the release of $\mathrm{A} \beta(1-42)$ HiLyte $^{\mathrm{TM}}$-Fluor555. The fit to a first-order kinetic process yields a maximum rate of the fluorescence decay of $(8.3 \pm 0.4) \cdot 10^{-3} \mathrm{~s}^{-1}$ (Figure 5D). Remarkably, this rate constant is about 10 -fold higher than the rate constant obtained for this reversion kinetic process with CaM. In addition, the calculated ratio between the half-times of complex formation and dissociation is $\approx 3$ for the $A \beta(1-42)$ :calbindin-D28k complexes, while the value obtained for $A \beta(1-42): C a M$ is 0.2 . Thus, our results allow us to conclude that CaM displays approximately 10-fold higher affinity for $\mathrm{A} \beta(1-42)$ than calbindin-D28k.

The synthetic peptide VFAFAMAFML (amidated-C-terminus amino acid) has been tested for its ability to antagonize $A \beta(1-42)$ :calbindin-D28k complex formation using $A \beta(1-$ 42) HiLyte ${ }^{\mathrm{TM}}$-Fluor555 (Figure 6). The results show that only submicromolar concentrations of this peptide are needed to inhibit the kinetic of increase of fluorescence that monitors the interaction between $10 \mathrm{nM} A \beta(1-42)$ HiLyte $^{\text {TM }}$-Fluor555 and $5 \mathrm{nM}$ CaM. Indeed, $250 \mathrm{nM}$ of VFAFAMAFML (amidated-C-terminus amino acid) almost completely block the kinetics of increase of fluorescence. An IC50 value of $27 \pm 3 \mathrm{nM}$ can be calculated from these results, as indicated in the legend of the Figure $6 \mathrm{~B}$.

\subsection{Docking between $A \beta(1-42)$ and Calbindin-D28k Gives Support to the Formation of $A \beta(1-42)$ :Calbindin-D28k Complexes}

As shown above, the hydrophobic peptide VFAFAMAFML (amidated-C-terminus amino acid) behaves as an antagonist against the formation of the $A \beta(1-42)$ :CaM complex and also against $A \beta(1-42)$ :calbindin-D28k complexes formation. This experimental observation led us to choose, within the highest-ranked hydrophobic-favored models yielded by the Cluspro server, only the simulations of the complex $A \beta(1-42)$ :calbindin-D28k displaying a large number of interactions with amino acid residues of the $A \beta(1-42)$ selected for the design of this peptide antagonist. Docking between $A \beta(1-42)$ and calbindin-D28k has been performed as indicated in the Materials and Methods section. As a result we found that docking with the A $\beta(1-42)$ PDB ID: 1IYT structure gave us more simulations of the $A \beta(1-42)$ :calbindin-D28k complex than PDB ID: $1 Z 0 Q$ with extensive interactions between the amino acid residues $24-42$ of $A \beta(1-42)$ and calbindin-D28k. This suggests that the microenvironment of the binding pocket of $A \beta(1-42)$ in calbindin-D28k is higher than in CaM, which is also in good agreement with the higher increase of the fluorescence of $\mathrm{A} \beta(1-42)$ HiLyte ${ }^{\mathrm{TM}}$-Fluor555 upon binding to calbindin-D28k. On these grounds, we obtained the PDB files of the 10 most probable structures after free energy minimization $(\Delta \mathrm{G})$ given by the ClusPro server for the A $\beta(1-42)$ PDB ID: 1 IYT, all with negative $\Delta \mathrm{G}$ values higher than $10 \mathrm{kcal} / \mathrm{mol}$. Therefore, docking simulations predict a high-affinity binding between $A \beta(1-42)$ and calbindin-D28k, which is in good agreement with the results obtained in fluorescence kinetic experiments. Three of the most probable structures for the complex $A \beta(1-42)$ :calbindin-D28k showed extensive interactions between the 24-42 amino acid residues of $A \beta(1-42)$ and calbindin-D28k. These are the model structures of the $A \beta(1-42)$ :calbindin-D28k complexes shown in the Figure 7, for which the docking simulation gives $\Delta \mathrm{G}$ values of $-17($ model 1$),-12($ model 2$)$ and $-11.6($ model 3) $\mathrm{kcal} / \mathrm{mol}$. 
Then, we selected these structures with the lowest $\Delta G$ values for interface analysis with PDBePISA, which yielded the amino acid residues of $\mathrm{A} \beta(1-42)$ and calbindin-D28k listed in the Table 2 as those whose microenvironment is more strongly altered by the interactions established in the $A \beta(1-42)$ :calbindin-D28k complex in the three selected models.
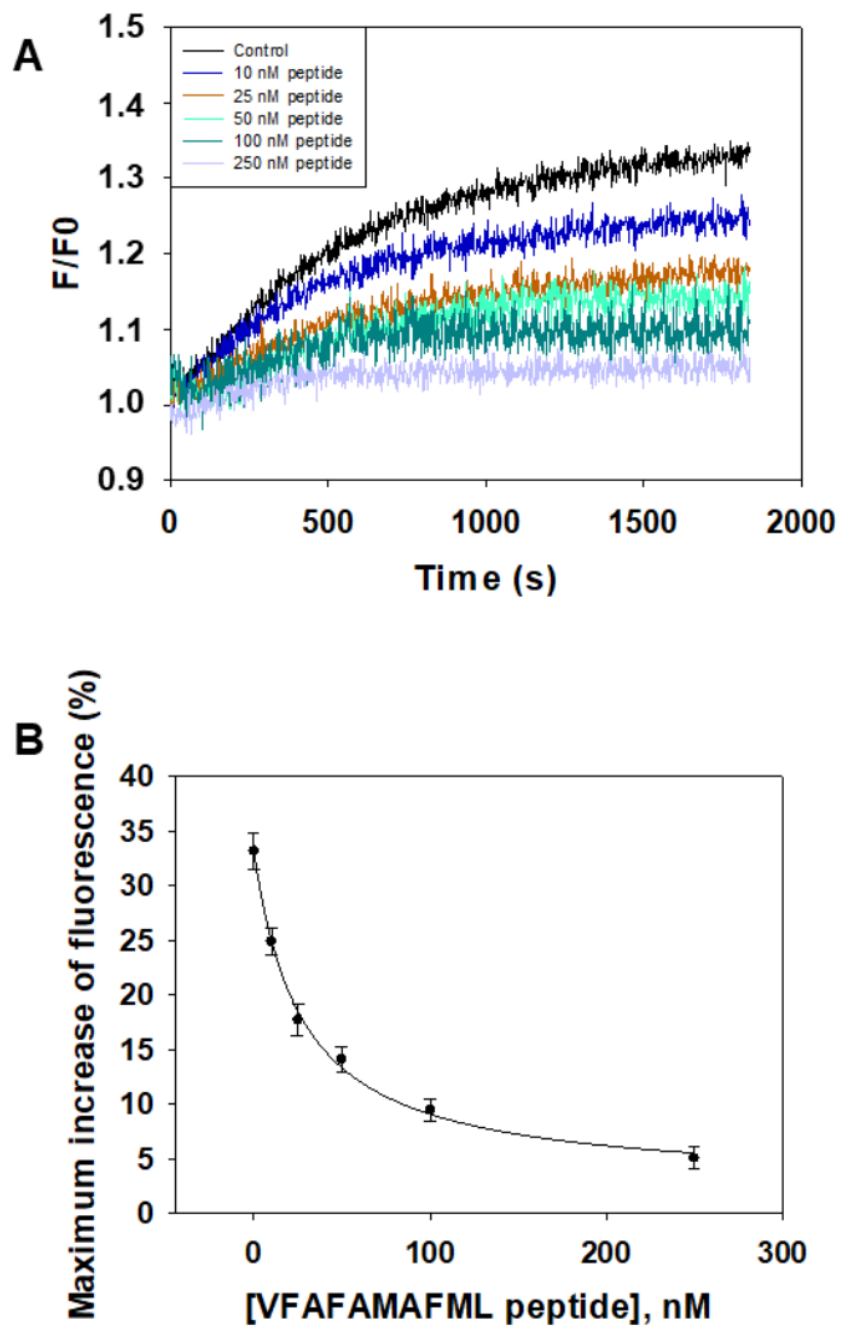

Figure 6. The synthetic peptide VFAFAMAFML (amidated-C-terminus amino acid) antagonizes $\mathrm{A} \beta(1-42)$ :calbindin-D28k complex formation. (A) Effect of increasing concentrations of this synthetic peptide on the kinetics of increase of the fluorescence intensity of $10 \mathrm{nM} \mathrm{A} \beta(1-42)$ HiLyte $^{\mathrm{TM}}$-Fluor555 after the addition of $5 \mathrm{nM}$ calbindin-D28k. Titration with the synthetic peptide and fluorescence measurements have been performed as indicated in the Materials and Methods. The kinetics of fluorescence were recorded in the presence of the following concentrations of the peptide VFAFAMAFML (amidated-C-terminus amino acid): 0 (black), $10 \mathrm{nM}$ (dark blue), $25 \mathrm{nM}$ (brown), $50 \mathrm{nM}$ (cyan), $100 \mathrm{nM}$ (green) and $250 \mathrm{nM}$ (grey). (B) Plot of the dependence of the maximum increase of fluorescence recorded $1700 \mathrm{~s}$ after the addition of calbindin-D28k as a function of the concentrations of the peptide VFAFAMAFML (amidated-C-terminus amino acid). The data shown are the average (black-filled circles) \pm S.E. (error bars) of the results obtained in triplicate measurements. The continuous line is the non-linear square fit of the data to the hyperbolic equation for a one site binding drug-inhibitory effect: $\mathrm{Y}=\mathrm{Y} 0-[\mathrm{Qmax} \times \mathrm{x} /(\mathrm{IC} 50+\mathrm{x})]$, where $\mathrm{Y} 0$ is the maximum fluorescence increase in the absence of the peptide, Qmax is the maximum quenching of the increase of fluorescence at saturation of the peptide and IC50 is the concentration of the peptide that reduces to half the maximum increase of fluorescence. The data fitting gave the following results: $\mathrm{R}^{2}=0.99694, \mathrm{Y} 0=33 \%, \mathrm{Qmax}=33 \%$ and IC50 $=27 \pm 3 \mathrm{nM}$. 


\section{Model Structure 1}

A

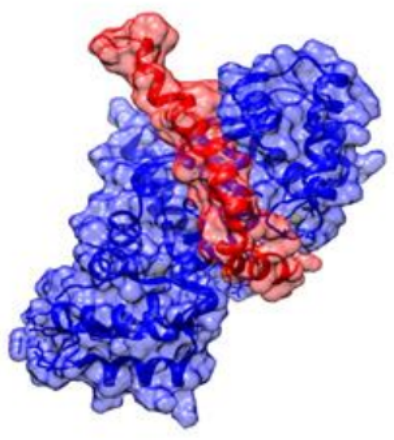

\section{Model Structure 2}

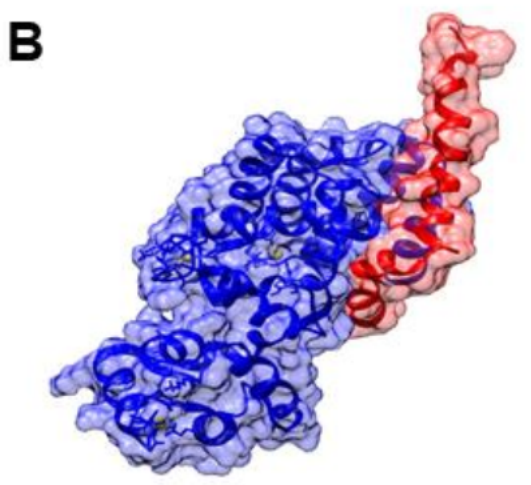

\section{Model Structure 3}

C

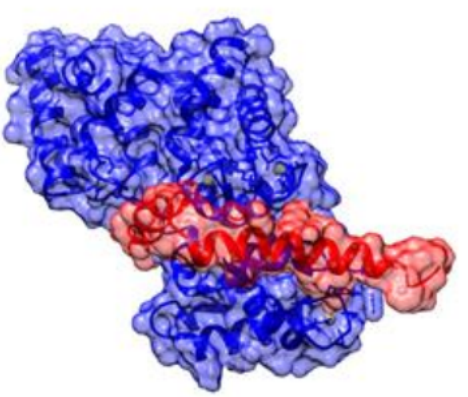

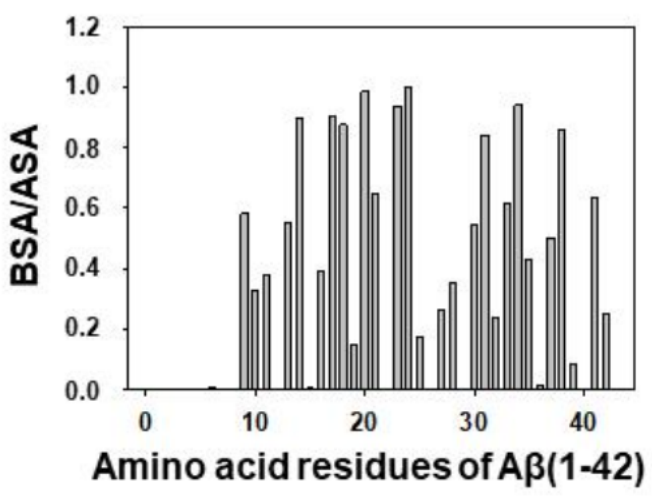
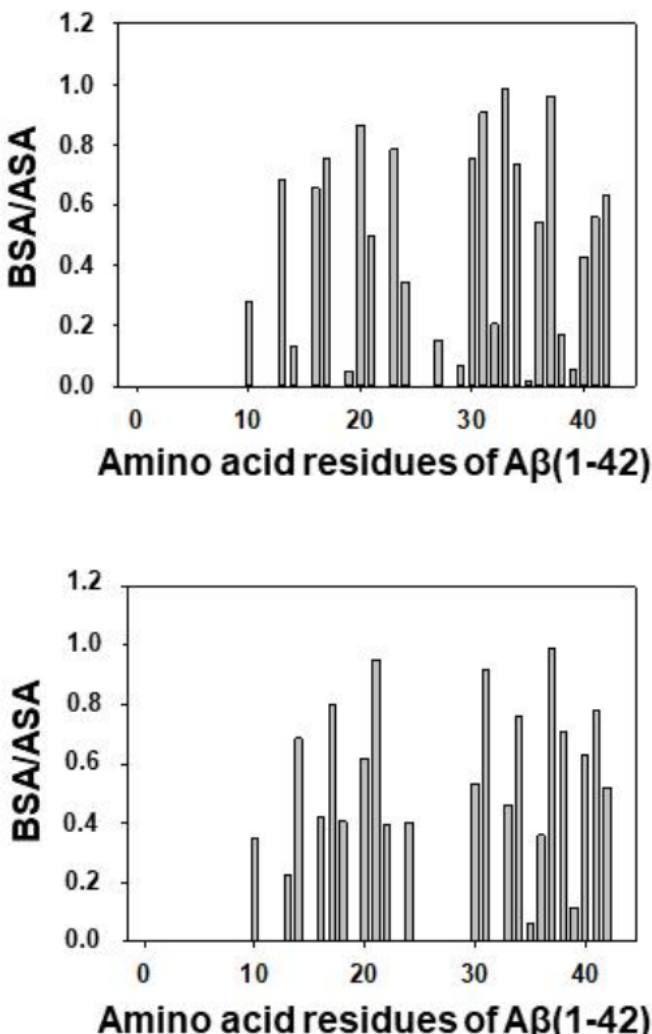

Figure 7. Selected in silico model structures of the complex $A \beta(1-42)$ :calbindin-D28k obtained using the PDB ID files: 1IYT for A $\beta(1-42)$ and 6FIE for calbindin-D28k. (A) Model structure 1. (B) Model Structure 2. (C) Model structure 3. For each model structure of the $A \beta(1-42)$ :calbindin-D28k complex a space-filled image with highlighted peptide and protein backbones is shown. $A \beta(1-42)$ is stained in red and calbindin-D28k is stained in blue in the space-filled image. The graphic charts of the BSA/ASA values obtained for the amino acids residues of $A \beta(1-42)$ in the in silico model structures 1 , 2 and 3 of the $A \beta(1-42)$ :calbindin-D28k complex are also shown in each panel (A-C) of this figure next (at the right-side) of each space-filled image. Docking was performed as indicated in the Materials and Methods. 
Table 2. List of strongly interacting amino acid residues of $A \beta(1-42)$ and calbindin-D28k in the selected model structures 1, 2 and 3 yielded by docking simulations for the 1:1 A $\beta(1-42)$ :calbindinD28k complex. The amino acid residues of both $A \beta(1-42)$ and calbindin-D28k are listed from high to lower values of the parameter BSA/ASA (values in parenthesis) obtained from the interface analysis with PDBePISA software. Only amino acid residues with BSA/ASA values $\geq 0.5$ for A $\beta(1-42)$ and $\geq 0.6$ for calbindin-D28k are listed.

\begin{tabular}{|c|c|c|}
\hline & $A \beta(1-42)$ Amino Acid Residues & $\begin{array}{c}\text { Calbindin-D28k Amino Acid } \\
\text { Residues }\end{array}$ \\
\hline Model structure 1 & $\begin{array}{c}\text { Val24 (1), Phe20 (0.98), Leu34 } \\
\text { (0.94), Asp23 (0.93), Leu17 (0.91), } \\
\text { His14 (0.90), Val18 (0.88), Gly38 } \\
\text { (0.86), Ile31 (0.84), Ala21 (0.65), } \\
\text { Ile41 (0.63), Gly33 (0.62), Ala30 } \\
\text { (0.55), Gly37 (0.52) }\end{array}$ & $\begin{array}{c}\text { Val173 (0.96), Ile73 (0.94), Val181 } \\
\text { (0.88), Leu179 (0.86), Lys72 (0.85), } \\
\text { Glu177 (0.85), His80 (0.84), Ser28 } \\
\text { (0.83), Glu57 (0.82), Phe61 (0.81), } \\
\text { Pro172 (0.68), Tyr30 (0.67), } \\
\text { Ser156 (0.61) }\end{array}$ \\
\hline Model structure 2 & $\begin{array}{c}\text { Gly33 (0.98), Gly37 (0.96), Ile31 } \\
\text { (0.91), Phe20 (0.86), Asp23 (0.78), } \\
\text { Leu17 (0.75), Ala30 (0.75), Leu34 } \\
\text { (0.74), His13 (0.68), Lys16 (0.66), } \\
\text { Ala42 (0.63), Ile41 (0.55), } \\
\text { Val36 (0.54) }\end{array}$ & $\begin{array}{l}\text { His80 (0.95), Arg47 (0.95), Pro172 } \\
\text { (0.92), Leu89 (0.82), Glu57 (0.78), } \\
\text { Arg93 (0.77), Leu82 (0.76), Lys98 } \\
\text { (0.74), Ser55 (0.74), Glu77 (0.73), Pro83 } \\
\text { (0.72), Leu52 (0.71), Val81 (0.63) }\end{array}$ \\
\hline Model structure 3 & $\begin{array}{l}\text { Gly37 (0.99), Ala21 (0.95), Ile31 } \\
\text { (0.92), Leu17 (0.80), Ile41 (0.78), } \\
\text { Leu34 (0.76), Gly38 (0.71), His14 } \\
\text { (0.69), Val40 (0.63), Phe20 (0.62), } \\
\text { Ala30 (0.53), Ala42 (0.52), }\end{array}$ & $\begin{array}{c}\text { Gly188 (0.99), Ser28 (0.95), Asn157 } \\
\text { (0.87), Ala258 (0.84), Glu166 (0.83), } \\
\text { Phe177 (0.80), Asn192 (0.72), Cys257 } \\
\text { (0.70), Arg249 (0.70), Ser156 (0.67), } \\
\text { Phe191 (0.67), Thr250 (0.63), } \\
\text { Gln182 (0.63) }\end{array}$ \\
\hline
\end{tabular}

\section{Discussion}

This work demonstrates that nanomolar concentrations of $A \beta(1-42)$ efficiently interact with the calcium-saturated forms of $\mathrm{CaM}$ and calbindin-D28k leading to the formation of stable $A \beta(1-42): C a M$ and $A \beta(1-42)$ :calbindin-D28k complexes. The latter result bears a particular relevance in brain neurons expressing calbindin-D28k. As noted in the introduction, this protein is abundant throughout the central nervous system including pyramidal hippocampal neurons and cortical neurons [33], which are in brain regions highly sensitive to neurodegeneration in AD. Since in a previous work [16] we found that the affinity of $\mathrm{A} \beta(1-42)$ for apo-CaM $\left(\mathrm{Ca}^{2+}\right.$-free $\left.\mathrm{CaM}\right)$ is about 20 -fold lower than for CaM saturated by $\mathrm{Ca}^{2+}$, we decided to focus this work in the $\mathrm{Ca}^{2+}$-saturated forms of these proteins. Also, it is to be noted that apo-CaM has a much more reduced regulatory role in neuronal activity than $\mathrm{Ca}^{2+}$-saturated $\mathrm{CaM}$, reviewed in [13]. The results of our previous experimental work of $A \beta(1-42)$ :CaM complexation led us to the conclusion that complexes with a 2:1 $A \beta(1-$ 42):calcium-binding protein complex stoichiometry are formed [16]. The results of this work also lend support to the formation of complexes with a 2:2 A $\beta(1-42)$ :calcium binding protein complex stoichiometry upon binding of a second molecule of CaM or calbindin-D28k to previously formed 2:1 A $\beta(1-42)$ :calcium binding protein complexes. Therefore, $\mathrm{CaM}$ and calbindin-D28k can buffer the free $\mathrm{A} \beta(1-42)$ concentration down to about $1 \mathrm{nM}$ in neurons expressing both proteins. The kinetic analysis of the formation rate of these complexes points out that CaM binds $A \beta(1-42)$ about two-fold more rapidly than calbindin-D28k. Thus, $C a M$ will bind $A \beta(1-42)$ more efficiently than calbindin-D28k. The fact that the rate of dissociation of $A \beta(1-42)$ from $A \beta(1-42)$ :CaM complexes is approximately 10-fold lower than the rate of formation of this complex give strong support to the hypothesis that a conformational reorganization takes place after the initial formation of the complex. A direct inspection of the $24-42$ amino acids domain of $A \beta(1-42)$ in the model structures 1 and 2 (Figures $2 \mathrm{~B}$ and $3 \mathrm{~B}$ ) reveals its distortion with respect to the structure of this peptide domain in PDB ID: 1IYT and 1Z0Q files. These structures were obtained by Nuclear Magnetic Resonance spectroscopy in 'helix-promoting' environments [34,35], and the results of 
our previous work [16] pointed out that the binding pocket of $A \beta(1-42)$ in CaM should be highly hydrophobic. As $A \beta(1-42)$ equilibrium between $\alpha$ and $\beta$ conformations represented by these PDB ID files is strongly dependent upon the polarity of the microenvironment [35], this structural distortion suggests that CaM binding shifts the equilibrium between $\alpha$ and $\beta$ structures of $A \beta(1-42)$. Indeed, the need for an early distortion of the 24-42 amino acids domain of $A \beta(1-42)$ might also account for the lag phase of about 1 min observed in the formation of $A \beta(1-42)$ :calbindin-D28k complexes. Overall, our results suggest a significant conformational flexibility of the C-terminal domain of $A \beta(1-42)$ upon binding to proteins. In addition, the docking analysis of the model structures of the $A \beta(1-42): C a M$ complex point out that Lys28 or Lys16 of $A \beta(1-42)$ are among the strongly interacting amino acid residues in the protein interface of the complex, it is likely that saline bridges further lock $A \beta(1-42)$ in the complex. The ratio values between the half-times of formation and dissociation of $\mathrm{A} \beta(1-42): \mathrm{CaM}$ and $\mathrm{A} \beta(1-42)$ :calbindin-D28k complexes indicate that the dissociation constant of $\mathrm{A} \beta(1-42)$ :calbindin-D28k complexes is around 10-fold higher than that of $A \beta(1-42): C a M$ complexes. Due to this, we conclude that CaM will prevail over calbindin-D28k for the trapping of $A \beta(1-42)$ concentrations in the nanomolar range in neurons expressing both proteins.

The dissociation rate of $A \beta(1-42)$ from $A \beta(1-42)$ : $C a M$ and from $A \beta(1-42)$ :calbindinD28k complexes is very slow in respect to the rate and frequency of many molecular events linked to repetitive synaptic activity. Since repetitive synaptic activity plays a key role in neuronal activity during learning and memory formation [36], and A $\beta(1-42)$ oligomers have been shown to impair synaptic efficiency [1,13,37], complexation of $A \beta(1-42)$ by CaM or calbindin-D28k can be seen as a protection mechanism against this stressor molecule in neurons. Interestingly, CaM-like skin protein, which is present at concentrations ranging between 3 and $6 \mathrm{nM}$ in the human cerebrospinal fluid [38], affords efficient protection against spatial learning impairment in a mouse model of AD [39] and inhibits neuronal death in a cell-based AD model [40]. But CaM or calbindin-D28k complexation can also be seen as a mechanism for adaptive response to $A \beta(1-42)$ oligomers-induced stress, because it will transduce the initial $A \beta(1-42)$ oligomers stress into cell signaling mediated by $\mathrm{A} \beta(1-42)$ : $\mathrm{CaM}$, and also in neurons expressing calbindin-D28k, by $\mathrm{A} \beta(1-42)$ :calbindinD28k complexes. Furthermore, in a previous work we reported that CaM binds not only $\mathrm{A} \beta(1-42)$ oligomers but also other highly neurotoxic peptides derived from $A \beta(1-42)$, like $\mathrm{A} \beta(25-35)$ [16]. Furthermore, $\mathrm{A} \beta(25-35)$ is the shortest that retains the toxicity of the full length peptide [41], and it has been suggested that this peptide is the biologically active region of $A \beta$ [42]. Other authors have also pointed out that the $A \beta(25-35)$ fragment is strongly neurotoxic, see for example [43-46]. In addition, using surface plasmon resonance Guo et al. [47] have shown that tau, another hallmark of AD, binds with nanomolar affinity to multiple $A \beta$ peptides in the mid to $C$-terminal regions of $A \beta$. On these grounds, we decided to select the docking model of the $A \beta(1-42): C a M$ complex displaying more interactions with the C-terminus domain of $A \beta(1-42)$, as the template for the design of a peptide with a high shielding efficiency for the amyloid peptide. Next, we experimentally assessed its ability to antagonize the formation of the $A \beta(1-42)$ :CaM complex.

The amino acid residues of $\mathrm{CaM}$ that docking simulations predicted to be directly involved in the interactions with the C-terminus domain of $A \beta(1-42)$ are highly hydrophobic. Considering their spatial organization in the CaM structure, we included a couple of additional hydrophobic amino acid residues as spacing groups. The designed peptide (from $\mathrm{N}$-terminus to $\mathrm{C}$-terminus): VFAFAMAFML (amidated-C-terminus amino acid) demonstrated to be a potent inhibitor of the formation of both $A \beta(1-42): C a M$ and $A \beta(1-$ 42):calbindin-D28k complexes. Thus, this result provides strong experimental support for the hypothesis that the initial formation of the $A \beta(1-42): C a M$ complex is driven by hydrophobic interactions. To further strengthen this point, docking simulations of interactions of the VFAFAMAFML peptide with $A \beta(1-42)$ and with the CaM conformation saturated by $\mathrm{Ca}^{2+}$ were performed using the CABS-dock web server as indicated in the Materials and methods section, without the need for any 'a priori' assumption of the 
peptide three-dimensional structure. The two most probable model structures yielded by this approach for the complexes between the VFAFAMAFML peptide and A $\beta(1-42)$ and $\mathrm{CaM}$ are presented in the Figure 8. In addition, this in silico analysis yielded several other model structures closely related to these model structures 1 and 2 within the 10 most probable outcomes. Direct visual inspection of the model structures shown in the Figure 8 allows to realize that the VFAFAMAFML peptide is likely interacting with the interface domains of $A \beta(1-42)$ and CaM that the ClusPro/PDBePISA approach predicted to be more strongly involved in the formation of $\mathrm{A} \beta(1-42)$ : CaM complexes. This result provides a plausible hypothesis for the antagonism of the $\mathrm{A} \beta(1-42)$ :CaM complexes formation by the VFAFAMAFML peptide. Also, this result suggests that the three-dimensional structure of the $A \beta(1-42)$ :CaM complex should be close to that used as a template model in this work. Because we measured in a previous study a dissociation constant of the $A \beta(1-42): C a M$ complex near $1 \mathrm{nM}$ [16], we focused on fluorescence, and we devised a method to monitor the formation of these complexes in the nanomolar range of concentrations. However, fluorescence spectroscopy cannot reach the atomic resolution level of protein complexes. On the other hand, experimental approaches which can be used for resolution of these complexes at an atomic level, like high-field Nuclear Magnetic Resonance or high-resolution Small-Angle X-Ray Scattering, requires the use of much higher concentrations of, both, $\mathrm{A} \beta(1-42)$ and CaM. Therefore, extensive experimental studies will be needed to resolve the three-dimensional structure of this complex at an atomic level, a point that is out of the scope of this work.

However, other hydrophobic peptides with alternate sequences of amino acid cannot be excluded, due to the weak strength of this type of short-range interactions and, also, by their low selectivity to discriminate between different hydrophobic side chains of amino acid residues. This is illustrated by those amino acid residues of calbindin-D28k forming paired interactions with the 25-42 amino acid residues of $A \beta(1-42)$ in the docking structures obtained for and A $\beta(1-42)$ :calbindin-D28k complexes. For example, the amino acid residues of calbindin-D28k with high BSA/ASA values in A $\beta(1-42)$ :calbindin-D28k complexes that are close to Ile31 of $A \beta(1-42)$ varies in the three model structures yielded by docking simulations: Val173 in structure 1; Leu89 and Arg93 in structure 2; Asn157 and Gln182 in structure 3. Similarly, docking simulations give high BSA/ASA values in $\mathrm{A} \beta(1-42)$ :calbindin-D28k complexes for the following amino acid residues of calbindinD28k located in the proximity of Ile41 of A $\beta(1-42)$ : Ser28, Phe61 and Tyr30 in structure 1; Pro172 in structure 2; Ser28 and Phe177 in structure 3. This variability of calbindin-D28k amino acid residues with high BSA/ASA values in A $\beta(1-42)$ :calbindin-D28k complexes is also highlighted by the amino acid residues displaying spatial vicinity to the short side chain Gly37/38 amino acid residues of $A \beta(1-42)$ : Ser28 and Ser156 in structure 1; Pro172 and Leu89 in structure 2; Ser28, Asn157, Phe177, Ser156 and Gln182 in structure 3. Comparing the calbindin-D28k amino acid residues with those of CaM highlights the possibility of designing a family of alternate peptides that could antagonize the formation of $A \beta(1-42)$ :CaM and $A \beta(1-42)$ :calbindin-D28k complexes. However, it is to be noted that further experimental work is needed to validate the most probable structure(s) of the A $\beta(1-42)$ :calbindin-D28k complex. Indeed, two experimental results included in this work strongly argue against model structure 2 in Figure 7 . First, the relatively high weight of the charged and polar amino acids residues of calbindin-D28k in the interface of model structure 2 is not consistent with the blockade of the formation of this complex by nanomolar concentrations of the strongly hydrophobic VFAFAMAFML (amidated-C-terminus amino acid) peptide. Second, the microenvironment of the HiLyteTM-Fluor555 dye attached to the N-terminus amino acid of $\mathrm{A} \beta(1-42)$ in this model structure 2 should not be significantly altered, which is against the conclusion derived from the fluorescence measurements. 
Model structures of the peptide VFAFAMAFML:A $\beta(1-42)$ complex

A
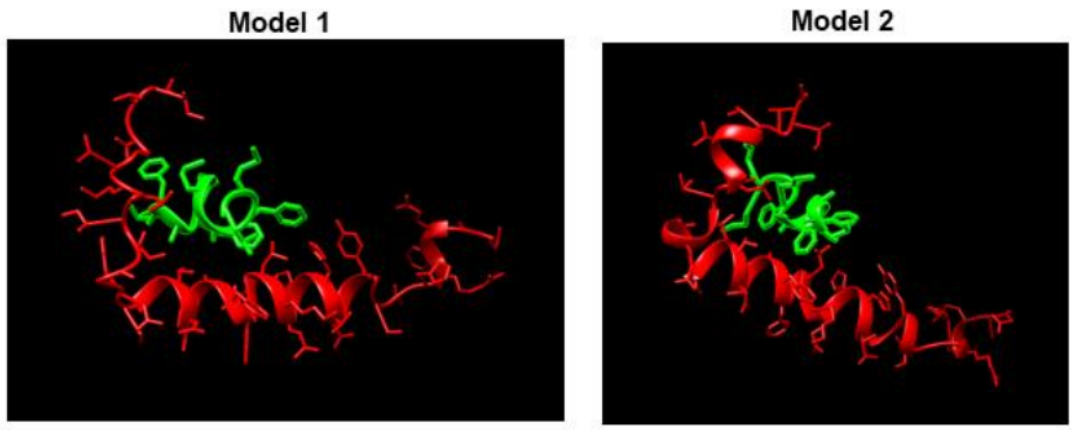

\section{Model structures of the peptide VFAFAMAFML:CaM complex}

B
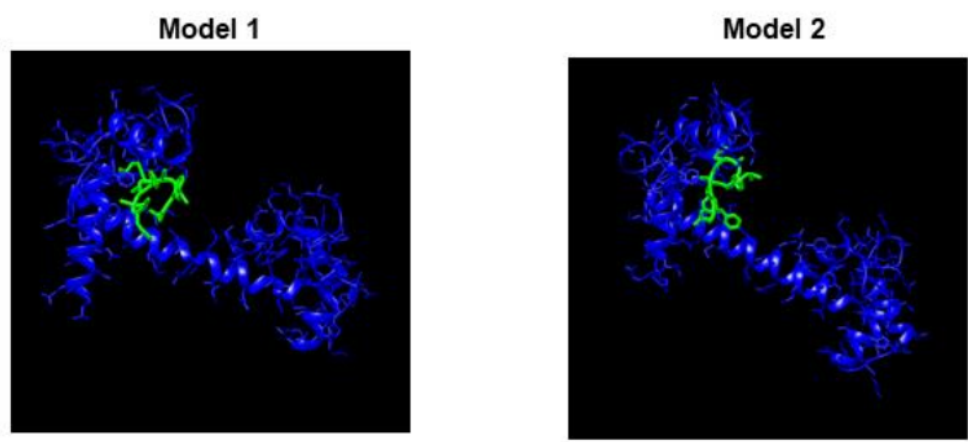

Figure 8. Highest-rank model structures of the complexes between the VFAFAMAFML peptide and $\mathrm{A} \beta(1-42)$ and $\mathrm{CaM}$ saturated with $\mathrm{Ca}^{2+}$ generated in silico by docking using the CABS-dock web server. (A) Model structures of the peptide VFAFAMAFML:A $\beta(1-42)$ complex. (B) Model structures of the peptide VFAFAMAFML:CaM complex. The two model structures with higher cluster density are shown for each complex, i.e., the two most probable structures yielded by the CABS-dock web server. Peptide backbones and side chains of amino acids are shown. The VFAFAMAFML peptide is colored in green, $A \beta(1-42)$ in red, and CaM in blue. See the Materials and methods section for more details.

The VFAFAMAFML (amidated-C-terminus amino acid) peptide antagonist against the formation of $\mathrm{A} \beta(1-42): \mathrm{CaM}$ and $\mathrm{A} \beta(1-42)$ :calbindin-D28k complexes designed in this study is highly hydrophobic, and its small size allows it to be envisaged that it can be rapidly incorporated within the cells. Moreover, we have experimentally assessed that the incubation of HT-22 cells in culture for $24 \mathrm{~h}$ with $0.1-1$ micromolar concentration of the antagonist peptide VFAFAMAFML (amidated-C-terminus amino acid) does not have any significant effect on cell viability (the data are included as supplementary material). Thus, it has a potential value for its therapeutic use by direct intracranial injection. However, the potential therapeutic use of this peptide by intravenous injections will require the evaluation of its permeability across the blood-brain barrier. In addition to the putative therapeutic use of the antagonist peptide developed and experimentally evaluated in this work, it may be useful for the evaluation of $A \beta(1-42)$ :CaM and $A \beta(1-42)$ :calbindin-D28k complexes relevance on the $A \beta(1-42)$-induced metabolic and functional dysregulation in brain neurons in culture. Moreover, this antagonist peptide provides the first template of amino acid residues sequence for the rational search for endogenous neuropeptides that can afford protection against $A \beta(1-42)$-induced neurotoxicity mediated by $A \beta(1-42): C a M$ and $A \beta(1-42)$ :calbindin-D28k complexes. The role of some endogenous neuropeptides as neuroprotection agents against the development of $\mathrm{AD}$ is a promising line of research that 
has been highlighted in several publications, see e.g., $[48,49]$. Furthermore, data pointing out that ghrelin, neurotensin, pituitary adenylate cyclase-activating polypeptide (PACAP), neuropeptide $\mathrm{Y}$, substance $\mathrm{P}$, and orexin may be associated with the pathophysiology and potential therapy of Alzheimer's disease has been reviewed in [49]. Interestingly, the amino acid residues of the N-terminus sequence of ghrelin are largely hydrophobic (UniProtKBQ9UBU3 (GHRL_HUMAN)), a significant reduction of ghrelin mRNA has been reported in the temporal gyrus of AD patients [50] and it has been proved that a single polymorphism mutation leading to a Gln/Leu substitution is associated with the onset age of AD [51].

In summary, the major novel findings reported in this work are: (1) the complexation between the nanomolar concentrations of $A \beta(1-42)$ and calbindin-D28k and (2) the submicromolar concentrations of the synthesized peptide VFAFAMAFML (amidated-Cterminus amino acid) designed in this work efficiently blocks the formation of $\mathrm{A} \beta(1-$ 42):CaM and $A \beta(1-42)$ :calbindin-D28k complexes. The latter results point out that the highly hydrophobic peptide VFAFAMAFML (amidated-C-terminus amino acid) could be useful as a tool to antagonize $A \beta(1-42): C a M$ and $A \beta(1-42)$ :calbindin-D28k complexes' formation in brain cells.

\section{Materials and Methods}

\subsection{Chemicals and Reagents}

Human A $\beta(1-42)-H_{i L y t e}{ }^{\mathrm{TM}}$-Fluor555 was obtained from AnaSpec (Freemont, CA, USA). The unlabeled A $\beta(1-42)$ were synthesized and supplied by StabVida (Caparica, Portugal) and GenicBio Limited (Shanghai, Popular Republic of China). The peptide VFAFAMAFML (amidated-C-terminus amino acid)—synthetized upon request and supplied by GenicBio Limited (Shanghai, Popular Republic of China)—was dissolved in dimethylsulfoxide (DMSO) at a concentration of $10 \mathrm{mM}$ and stored at $-20{ }^{\circ} \mathrm{C}$ until use. Purified bovine brain CaM, HisTrap ${ }^{\mathrm{TM}}$ FF and a Thrombin Clean Cleavage ${ }^{\mathrm{TM}}$ kit were purchased from Sigma-Aldrich (Madrid, Spain). Microcolumns NZYMiniPrep were acquired from NZYTech (Lisbon, Portugal).

All other reagents and chemicals were of analytical grade from Sigma-Aldrich (Madrid, Spain), Roche-Merck (Darmstadt, Germany), and ThermoFisher Scientific (Madrid, Spain).

\subsection{A $\beta(1-42)$ Solutions and Aggregation State}

The $A \beta(1-42)$ solutions were prepared by dissolving the solid lyophilized peptide in $1 \% \mathrm{NH}_{4} \mathrm{OH}$ and diluted with phosphate-buffered saline to the desired concentration, as in [16]. The aggregation states of the $A \beta(1-42)$ stock solutions used in this work were evaluated using the rapid photoinduced cross-linking of unmodified proteins approach as described in detail in [17]. Dimers are the predominant aggregation state of $A \beta(1-42)$ in our $2 \mu \mathrm{M}$ of stock solutions, with a minor $(<10 \%)$ contribution of trimers and undetectable concentration of $\mathrm{A} \beta(1-42)$ monomers.

\subsection{Expression and Purification of Calbindin-D28k}

The protocol for expressing and purifying calbindin-D28k was derived from [52] with minor modifications. We purchased an already cloned into pET15b codon-optimized cDNA for CALB1 expression in E. coli, with flanking restriction sites for NcoI and BamHI (GenScript, Piscataway, NJ, USA). The BL-21 (DE3) competent cells were transformed with $50 \mathrm{ng} / \mathrm{mL}$ of the recombinant plasmid pET-15b-CALB1 and transformants were platted in lysogeny broth (LB) agar supplemented with $100 \mu \mathrm{g} / \mathrm{mL}$ of ampicillin overnight at $37^{\circ} \mathrm{C}$. A single colony containing the recombinant plasmid was inoculated into $5 \mathrm{~mL}$ of LB media supplemented with ampicillin $(100 \mu \mathrm{g} / \mathrm{mL})$ and grown at $37^{\circ} \mathrm{C}$ for $12 \mathrm{~h}$ under shaking. This culture was used to inoculate $1 \mathrm{~L}$ of the same media kept with the same growing conditions. Once the cellular optic density reached 0.6 , protein expression was induced by adding $0.4 \mathrm{mM}$ of isopropyl- $\beta$-D-thiogalactoside (IPTG) to the media, and the culture was kept under shaking at $200 \mathrm{rpm}$ at $25^{\circ} \mathrm{C}$ for $10-12 \mathrm{~h}$. 
Next, the cells were spined down by centrifugation at $6000 \times g$ for $30 \mathrm{~min}$. The pellets were collected and resuspended in the following buffer: $150 \mathrm{mM}$ of tris-(hydroxymethyl) aminomethane (Tris- $\mathrm{HCl}$ ), $150 \mathrm{mM}$ of $\mathrm{NaCl}, 50 \mathrm{mM}$ of $\mathrm{MgCl}_{2}, 1 \mathrm{mM}$ of phenylmethylsulfonyl fluoride, and $1 \mathrm{mg} / \mathrm{mL}$ of lysozyme ( $\mathrm{pH}$ 8), and kept under stirring for $90 \mathrm{~min}$ at 4 ${ }^{\circ} \mathrm{C}$. The cells were lysed with two freeze/thaw cycles at $-80{ }^{\circ} \mathrm{C}$ and at room temperature. After this point, $0.2 \%$ sodium deoxycholate was added to the media to ensure a better solubilization of the cellular content. The DNA released by the cells was removed by the addition of $0.05 \mathrm{mg} / \mathrm{mL}$ of DNAse. The lysate was centrifuged at $8000 \times g$ for $30 \mathrm{~min}$, and the supernatant was collected and brought to $\mathrm{pH}$ 8.0. The recombinant CALB1 containing the poly His-tail protein was purified using affinity chromatography columns (HisTrap ${ }^{\mathrm{TM}}$-FF). The supernatant was loaded onto a $10 \mathrm{~mL}$ prepacked HisTrap ${ }^{\mathrm{TM}}$-FF chromatographical support equilibrated with a buffer of $20 \mathrm{mM}$ of Tris- $\mathrm{HCl}, 0.5 \mathrm{M}$ of $\mathrm{NaCl}$, and $10 \mathrm{mM}$ of imidazole ( $\mathrm{pH} 7.4)$. After washing with a buffer (10 volumes), the proteins retained into the column were eluted with a buffer supplemented with $250 \mathrm{mM}$ of imidazole. The almost pure recombinant calbindin-D28k was loaded onto a Sephadex G75 column $(1 \times 50 \mathrm{~cm})$ equilibrated with $50 \mathrm{mM}$ of Tris- $\mathrm{HCl}(\mathrm{pH}$ 7.5) to further purify the protein from undesired contaminants. After this step, the protein purity was assessed by sodium dodecyl sulfate-polyacrylamide gel electrophoresis (SDS-PAGE) (Supplementary Figure S1) and the protein yield obtained after each one of the purification steps is listed in Table S1, included in Supplementary Figure S1. Purified protein batches were kept at $-80{ }^{\circ} \mathrm{C}$ until use.

The Poly-Histidine ${ }_{6}$ tag was cut by overnight incubation with a Thrombin Clean Cleavage $^{\mathrm{TM}}$ kit. The purified recombinant calbindin-D28k protein was separated from the generated peptide by chromatography using a Sephadex G75 column of $1 \mathrm{~cm}$ diameter $\times 25 \mathrm{~cm}$ length. The treatment efficiency for the removal of the poly-His 6 tail was assessed by SDS-PAGE (Supplementary Figure S1). Calbindin-D28k concentration was determined using an extinction coefficient of $27,957-28,037 \mathrm{M}^{-1} \mathrm{~cm}^{-1}$ at $280 \mathrm{~nm}[53,54]$. In this work, we have routinely obtained fractions of purified recombinant calbindin-D28k with concentrations in the range 15 and $20 \mu \mathrm{M}$ per batch, i.e., between 0.48 and $0.64 \mathrm{mg}$ of protein $/ \mathrm{mL}$.

\subsection{Measurements of A (1-42) HiLyte ${ }^{T M}$-Fluor555 Interaction with CaM and Calbindin-D28k}

The fluorescence measurements were performed using a Fluoromax+ fluorescence Spectrophotometer (Jovin Yvon technologies) at room temperature $\left(24-25^{\circ} \mathrm{C}\right.$ ) in quartz cells of $1 \mathrm{~cm}$ light-pathlength, with excitation and emission slits set to $5 \mathrm{~nm}$.

The measurements of the kinetics of interaction were performed by adding $10 \mathrm{nM}$ of A $\beta(1-42)$ HiLyte $^{\text {TM }}$-Fluor555 in a buffer of $50 \mathrm{mM}$ of $N$-[2-hydroxyethyl] piperazine- $N^{\prime}$-[2ethanesulfonic acid] (Hepes), $100 \mathrm{mM}$ of $\mathrm{KCl}$ and $50 \mu \mathrm{M}$ of $\mathrm{CaCl}_{2}$ (pH 7.05). The cuvette was kept with magnetic stirring in the dark within the cuvette holder of the fluorimeter until the stabilization of the fluorescence intensity, routinely between 20 and $40 \mathrm{~min}$. Then, CaM or calbindin-D28k were added to the cuvette at the concentrations indicated in the figures, and the kinetics of the fluorescence intensity were recorded with excitation and emission wavelengths of $520 \mathrm{~nm}$ and $567 \mathrm{~nm}$, respectively.

\subsection{In silico Docking Experiments}

The docking experiments were performed using ClusPro, a web server that performs the docking of two proteins by sampling billions of conformations. This server performs the following computational steps: (i) rigid-body coupling by sampling trillions of conformations; (ii) the clustering base calculated the root mean square deviation (RMSD) of the 1000 structure with the lowest energy generated, to find the clusters that will represent the most probable models of the complex; (iii) the refinement of the selected structure using energy minimization. The following PDB files were used for the determination of the interacting interface between $\mathrm{A} \beta(1-42)$ and $\mathrm{CaM}$ and calbindin-D28k:CaM saturated with calcium (PDB ID:1CLL), calbindin-D28k saturated with calcium (PDB ID: 6FIE), and the $A \beta(1-42)$ structures (PDB ID:1IYT and/or 1Z0Q as indicated for each case). Due to 
the reported conformational changes in the C-terminus domain of $A \beta(1-42)$ induced by changes in the microenvironment's hydrophobicity [35], we have used two PDB ID files for $A \beta(1-42)$, i.e., PDB ID $1 Z 0 Q$ and 1 IYT, as representative of the $A \beta(1-42)$ conformations predominant in water and in a strongly hydrophobic environment, respectively. The top 10 highest ranked models for complex formation were selected for initial analysis in order to quantify the amino acid residues present at the interface. Interface analysis was performed with PDBe PISA (Protein, Interface, Surface, and Assemblies), available at https: / / www.ebi.ac.uk/pdbe/pisa. Last access for interface analysis of the A $\beta(1-42): C a M$ complex on 11 November 2019, and last access for interface analysis of A $\beta(1-42)$ :calbindinD28k complex on 3 January 2022. The hidden or buried surface area/accessible surface area ratio (BSA/ASA ratio) of the most likely complex simulations were used to quantify the involvement degree of each amino acid residue in the formation of the complex. A threshold level of $0.5-0.6$ was chosen to select the amino acid residues that strongly contributed to the interacting surface. Plots and molecular analysis were performed with the UCSF Chimera package.

The modeling of protein-peptide interactions was performed using the CABS-dock web server (http: / / biocomp.chem.uw.edu.pl/CABSdock, accessed on 1 February 2022) [55,56], as in a previous work [16]. The PDB files used in this docking analysis are: 1CLL for CaM saturated with $\mathrm{Ca}^{2+}$ and 1IYT for $\mathrm{A} \beta(1-42)$.

\subsection{Experimental Evaluation of the Efficiency of the Designed Peptide to Antagonize the Interaction between $A \beta(1-42)$ HiLyte ${ }^{T M}$-Fluor555 and CaM or Calbindin-D28k}

The measurements of the experimental evaluation of the efficiency of the designed peptide were carried out with $10 \mathrm{nM}$ of $\mathrm{A} \beta(1-42)$ HiLyte $^{\mathrm{TM}}-$ Fluor555 preincubated for 10-15 min with different concentrations of the peptide in buffer $50 \mathrm{mM}$ of Hepes, $100 \mathrm{mM}$ of $\mathrm{KCl}$, and $50 \mu \mathrm{M}$ of $\mathrm{CaCl}_{2}$ ( $\mathrm{pH}$ 7.05) before the addition of CaM or calbindin-D28k. The peptide VFAFAMAFML (amidated-C-terminus amino acid) was added from concentrated stock solutions in DMSO, taking care that the DMSO concentration was always between 0.05 and $0.1 \%$ in the cuvette of fluorescence measurements. The kinetic assays were made with excitation and emission wavelengths of $520 \mathrm{~nm}$ and $567 \mathrm{~nm}$, and the kinetics of fluorescence were recorded after the addition of CaM or calbindin-D28k at the concentrations indicated in the figures' captions. Experiments run with 0.05 and $0.1 \%$ DMSO showed no effect of this DMSO concentrations on these kinetics of fluorescence in the absence of the peptide.

\subsection{Statistical Analysis}

The results were expressed as the mean standard error (S.E.). Statistical analysis was carried out by the Student t-test. A significant difference was accepted at the $p<0.05$ level. All results were confirmed in triplicate experiments.

Supplementary Materials: The following are available online at https:/ /www.mdpi.com/article/10 $.3390 /$ ijms23042289/s1.

Author Contributions: J.S. has been the author performing the initial in silico analysis of the complexes and most of the experimental work, including the production and purification of calbindinD28k. J.P. has been collaborating with J.S. in fluorescence measurements and primary analysis of the results, as well as in laboratory handlings needed for the preparations of peptides and protein samples needed for experimental assays and in the integrative analysis of the results. A.M.M. has collaborated in the methodological setup, in the critical analysis of the results and in the funding acquisition and administration of the research grant which allowed the development of this work. A.K.S.-A. has collaborated in the docking analysis performed in this work and in the expression and purification of calbindin-D28k. C.G.-M. designed the goals of this work and the overall methodological setup, distributed the tasks between the members of the research team, supervised the docking analysis and fluorescence measurements, critically evaluated all the results and has been responsible for the funding of this project. The original draft was written by J.S. and C.G.-M., and all authors J.S., J.P., A.M.M., A.K.S.-A. and C.G.-M. have collaborated in the review and editing of the article submitted for publication. Conceptualization, C.G.-M.; methodology, J.S., J.P., A.M.M., A.K.S.-A. and C.G.-M.; 
software, J.S., A.K.S.-A. and C.G.-M.; validation, J.S., A.K.S.-A. and C.G.-M.; formal analysis, J.S., J.P., A.K.S.-A. and C.G.-M.; investigation, J.S., J.P., A.M.M., A.K.S.-A. and C.G.-M.; data curation, J.S., A.K.S.-A. and C.G.-M.; writing-original draft preparation, J.S. and C.G.-M.; writing-review and editing, J.S., J.P., A.M.M., A.K.S.-A. and C.G.-M.; supervision, C.G.-M.; project administration, C.G.-M. and A.M.M.; funding acquisition, C.G.-M. and A.M.M. All authors have read and agreed to the published version of the manuscript.

Funding: This work has been supported by Grant BFU2017-85723-P of the Spanish Ministerio de Ciencia, Innovación y Universidades (Spanish National R\&D program) to Ana M. Mata and Carlos Gutierrez-Merino, and was co-financed by the European Funds for Structural Development (FEDER).

Institutional Review Board Statement: Not applicable.

Informed Consent Statement: Not applicable.

Data Availability Statement: Not applicable.

Acknowledgments: Jairo Salazar has been supported by a Predoctoral Fellowship of the Spanish Fundación Carolina (Madrid, Spain).

Conflicts of Interest: The authors declare no conflict of interest.

\section{Abbreviations}

\begin{tabular}{|c|c|}
\hline$A \beta$ & amyloid $\beta$ \\
\hline $\mathrm{AD}$ & Alzheimer's disease \\
\hline BSA/ASA & buried surface area/accessible surface area ratio \\
\hline CaM & calmodulin \\
\hline DMSO & dimethylsulfoxide \\
\hline Hepes & $N$-[2-hydroxyethyl] piperazine- $N^{\prime}$-[2-ethanesulfonic acid] \\
\hline IC50 & concentration producing $50 \%$ of the maximum effect \\
\hline IPTG & isopropyl- $\beta$-D-thiogalactoside \\
\hline LB & lysogeny broth \\
\hline Qmax & maximum extinction of fluorescence \\
\hline SDS-PAGE & sodium dodecyl sulfate-polyacrylamide gel electrophoresis \\
\hline S.E. & standard error \\
\hline Tris & tris-(hydroxymethyl) aminomethane \\
\hline
\end{tabular}

\section{References}

1. Walsh, D.M.; Klyubin, I.; Fadeeva, J.V.; Cullen, W.K.; Anwyl, R.; Wolfe, M.S.; Rowan, M.J.; Selkoe, D.J. Naturally secreted oligomers of amyloid beta protein potently inhibit hippocampal long-term potentiation in vivo. Nature 2002, 416, 535-539. [CrossRef]

2. Hu, X.; Crick, S.L.; Bu, G.; Frieden, C.; Pappu, R.V.; Lee, J.-M. Amyloid seeds formed by cellular uptake, concentration, and aggregation of the amyloid- $\beta$ peptide. Proc. Natl. Acad. Sci. USA 2009, 106, 20324-20329. [CrossRef]

3. Friedrich, R.P.; Tepper, K.; Rönicke, R.; Soom, M.; Westermann, M.; Reymann, K.; Kaether, C.; Fändrich, M. Mechanism of amyloid plaque formation suggests an intracellular basis of A $\beta$ pathogenicity. Proc. Natl. Acad. Sci. USA 2010, 107, 1942-1947. [CrossRef]

4. Jin, S.; Kedia, N.; Illes-Toth, E.; Haralampiev, I.; Prisner, S.; Herrmann, A.; Wanker, E.E.; Bieschke, J. Amyloid- $\beta(1-42)$ Aggregation Initiates Its Cellular Uptake and Cytotoxicity. J. Biol. Chem. 2016, 291, 19590-19606. [CrossRef] [PubMed]

5. Wirths, O.; Multhaup, G.; Czech, C.; Blanchard, V.; Moussaoui, S.; Tremp, G.; Pradier, L.; Beyreuther, K.; Bayer, T.A. Intraneuronal $\mathrm{A} \beta$ accumulation precedes plaque formation in $\beta$-amyloid precursor protein and presenilin-1 double-transgenic mice. Neurosci. Lett. 2001, 306, 116-120. [CrossRef]

6. Oddo, S.; Caccamo, A.; Shepherd, J.D.; Murphy, M.P.; Golde, T.E.; Kayed, R.; Metherate, R.; Mattson, M.P.; Akbari, Y.; LaFerla, F.M. Triple-transgenic model of Alzheimer's disease with plaques and tangles: Intracellular A $\beta$ and synaptic dysfunction. Neuron 2003, 39, 409-421. [CrossRef]

7. Oakley, H.; Cole, S.L.; Logan, S.; Maus, E.; Shao, P.; Craft, J.; Guillozet-Bongaarts, A.; Ohno, M.; Disterhoft, J.; Van Eldik, L.; et al. Intraneuronal $\beta$-amyloid aggregates, neurodegeneration, and neuron loss in transgenic mice with five familial Alzheimer's disease mutations: Potential factors in amyloid plaque formation. J. Neurosci. 2006, 26, 10129-10140. [CrossRef]

8. Knobloch, M.; Konietzko, U.; Krebs, D.C.; Nitsch, R.M. Intracellular A $\beta$ and cognitive deficits precede $\beta$-amyloid deposition in transgenic arcA $\beta$ mice. Neurobiol. Aging 2007, 28, 1297-1306. [CrossRef]

9. Zhang, Y.; McLaughlin, R.; Goodyer, C.G.; Leblanc, A.C. Selective cytotoxicity of intracellular amyloid $\beta$ peptide1-42 through p53 and Bax in cultured primary human neurons. J. Cell Biol. 2002, 156, 519-529. [CrossRef] 
10. Kuchibhotla, K.V.; Goldman, S.T.; Lattarulo, C.R.; Wu, H.-Y.; Hyman, B.T.; Bacskai, B.J. A $\beta$ Plaques Lead to Aberrant Regulation of Calcium Homeostasis In Vivo Resulting in Structural and Functional Disruption of Neuronal Networks. Neuron 2008, 59, 214-225. [CrossRef]

11. Lopez, J.R.; Lyckman, A.; Oddo, S.; LaFerla, F.M.; Querfurth, H.W.; Shtifman, A. Increased intraneuronal resting [Ca2+] in adult Alzheimer's disease mice. J. Neurochem. 2008, 105, 262-271. [CrossRef]

12. Berridge, M.J. Calcium Signalling and Alzheimer's Disease. Neurochem. Res. 2011, 36, 1149-1156. [CrossRef]

13. Poejo, J.; Salazar, J.; Mata, A.M.; Gutierrez-Merino, C. The Relevance of Amyloid $\beta$-Calmodulin Complexation in Neurons and Brain Degeneration in Alzheimer's Disease. Int. J. Mol. Sci. 2021, 22, 4976. [CrossRef]

14. Biber, A.; Schmid, G.; Hempel, K. Calmodulin content in specific brain areas. Exp. Brain Res. 1984, 56, 323-326. [CrossRef]

15. Xia, Z.; Storm, D.R. The role of calmodulin as a signal integrator for synaptic plasticity. Nat. Rev. Neurosci. 2005, 6, 267-276. [CrossRef]

16. Corbacho, I.; Berrocal, M.; Török, K.; Mata, A.M.; Gutierrez-Merino, C. High affinity binding of amyloid $\beta$-peptide to calmodulin: Structural and functional implications. Biochem. Biophys. Res. Commun. 2017, 486, 992-997. [CrossRef]

17. Poejo, J.; Salazar, J.; Mata, A.; Gutierrez-Merino, C. Binding of Amyloid $\beta(1-42)$-Calmodulin Complexes to Plasma Membrane Lipid Rafts in Cerebellar Granule Neurons Alters Resting Cytosolic Calcium Homeostasis. Int. J. Mol. Sci. 2021, $22,1984$. [CrossRef]

18. Laurén, J.; Gimbel, D.A.; Nygaard, H.B.; Gilbert, J.W.; Strittmatter, S.M. Cellular prion protein mediates impairment of synaptic plasticity by amyloid- $\beta$ oligomers. Nat. Cell Biol. 2009, 457, 1128-1132. [CrossRef]

19. Dunning, C.J.; McGauran, G.; Willén, K.; Gouras, G.K.; O'Connell, D.J.; Linse, S. Direct High Affinity Interaction between A $\beta 42$ and GSK3 $\alpha$ Stimulates Hyperphosphorylation of Tau. A New Molecular Link in Alzheimer's Disease? ACS Chem. Neurosci. 2015, 7, 161-170. [CrossRef]

20. O'Day, D.H. Calmodulin Binding Proteins and Alzheimer's Disease: Biomarkers, Regulatory Enzymes and Receptors That Are Regulated by Calmodulin. Int. J. Mol. Sci. 2020, 21, 7344. [CrossRef]

21. Christakos, S.; Gabrielides, C.; Rhoten, W.B. Vitamin D-dependent calcium binding proteins: Chemistry, distribution, functional considerations and molecular biology. Endocr. Rev. 1989, 10, 3-26. [CrossRef] [PubMed]

22. Pasti, L.; Carmignoto, G.; Pozzan, T.; Battini, R.; Ferrari, S.; Lally, G.; Emson, P.C. Cellular calcium handling in brain slices from calbindin D28k-deficient mice. Neuroreport 1999, 10, 2367-2372. [CrossRef] [PubMed]

23. Palop, J.J.; Jones, B.; Kekonius, L.; Chin, J.; Yu, G.-Q.; Raber, J.; Masliah, E.; Mucke, L. Neuronal depletion of calcium-dependent proteins in the dentate gyrus is tightly linked to Alzheimer's disease related cognitive deficits. Proc. Natl. Acad. Sci. USA 2003, 100, 9572-9577. [CrossRef] [PubMed]

24. Greene, J.R.; Radenahmad, N.; Wilcock, G.K.; Neal, J.W.; Pearson, R.C. Accumulation of calbindin in cortical pyramidal cells with ageing; a putative protective mechanism which fails in Alzheimer's disease. Neuropathol. Appl. Neurobiol. 2001, 27, 339-342. [CrossRef]

25. Guo, Q.; Christakos, S.; Robinson, N.; Mattson, M.P. Calbindin D28k blocks the proapoptotic actions of mutant presenilin 1: Reduced oxidative stress and preserved mitochondrial function. Proc. Natl. Acad. Sci. USA 1998, 95, 3227-3232. [CrossRef] [PubMed]

26. Wernyj, R.P.; Mattson, M.P.; Christakos, S. Expression of calbindin-D28k in C6 glial cells stabilizes intracellular calcium levels and protects against apoptosis induced by calcium ionophore and amyloid beta-peptide. Brain Res. Mol. Brain Res. 1999, 64, 69-79. [CrossRef]

27. Kook, S.-Y.; Jeong, H.; Kang, M.J.; Park, R.; Shin, H.J.; Han, S.-H.; Son, S.M.; Song, H.; Baik, S.H.; Moon, M.; et al. Crucial role of calbindin-D28k in the pathogenesis of Alzheimer's disease mouse model. Cell Death Differ. 2014, 21, 1575-1587. [CrossRef] [PubMed]

28. dos Santos, V.V.; Santos, D.B.; Lach, G.; Rodrigues, A.L.; Farina, M.; De Lima, T.C.; Prediger, R.D. Neuropeptide Y (NPY) prevents depressive-like behavior, spatial memory deficits and oxidative stress following amyloid- $\beta$ [A $\beta(1-40)]$ administration in mice. Behav. Brain Res. 2013, 244, 107-115. [CrossRef]

29. Kang, S.; Moon, N.R.; Kim, D.S.; Kim, S.H.; Park, S. Central acylated ghrelin improves memory function and hippocampal AMPK activation and partly reverses the impairment of energy and glucose metabolism in rats infused with $\beta$-amyloid. Peptides $\mathbf{2 0 1 5}$ 71, 84-93. [CrossRef]

30. Santos, V.V.; Stark, R.; Rial, D.; Silva, H.B.; Bayliss, J.A.; Lemus, M.B.; Davies, J.S.; Cunha, R.A.; Prediger, R.D.; Andrews, Z.B. Acyl ghrelin improves cognition, synaptic plasticity deficits and neuroinflammation following amyloid $\beta$ (A $\beta 1-40)$ administration in mice. J. Neuroendocrinol. 2017, 29, 1-11. [CrossRef]

31. Martins, I.; Gomes, S.; Costa, R.O.; Otvos, L.; Oliveira, C.R.; Resende, R.; Pereira, C.M.F. Leptin and ghrelin prevent hippocampal dysfunction induced by A $\beta$ oligomers. Neuroscience 2013, 241, 41-51. [CrossRef]

32. Gomes, S.; Martins, I.; Fonseca, A.C.; Oliveira, C.R.; Resende, R.; Pereira, C.M. Protective effect of leptin and ghrelin against toxicity induced by amyloid- $\beta$ oligomers in a hypothalamic cell line. J. Neuroendocrinol. 2014, 26, 176-185. [CrossRef]

33. Baimbridge, K.G.; Celio, M.R.; Rogers, J.H. Calcium-binding proteins in the nervous system. Trends Neurosci. 1992, 15, 303-308. [CrossRef] 
34. Crescenzi, O.; Tomaselli, S.; Guerrini, R.; Salvadori, S.; D'Ursi, A.M.; Temussi, P.A.; Picone, D. Solution structure of the Alzheimer amyloid beta-peptide (1-42) in an apolar microenvironment: Similarity with a virus fusion domain. Eur. J. Biochem. 2002, 269, 5642-5648. [CrossRef]

35. Tomaselli, S.; Esposito, V.; Vangone, P.; van Nuland, N.A.J.; Bonvin, A.M.J.J.; Guerrini, R.; Tancredi, T.; Temussi, P.A.; Picone, D. The $\alpha$-to- $\beta$ Conformational Transition of Alzheimer's A $\beta-(1-42)$ Peptide in Aqueous Media is Reversible: A Step by Step Conformational Analysis Suggests the Location of $\beta$ Conformation Seeding. ChemBioChem 2006, 7, 257-267. [CrossRef]

36. Brady, S.; Siegel, G.; Wayne Albers, R.; Price, D.L. Basic Neurochemistry: Principles of Molecular, Cellular, and Medical Neurobiology, 8th ed.; Academic Press/Elsevier: Amsterdam, The Netherlands, 2011.

37. Bahr, B.A.; Hoffman, K.B.; Yang, A.J.; Hess, U.S.; Glabe, C.G.; Lynch, G. Amyloid $\beta$ protein is internalized selectively by hippocampal field CA1 and causes neurons to accumulate amyloidogenic carboxyterminal fragments of the amyloid precursor protein. J. Comp. Neurol. 1998, 397, 139-147. [CrossRef]

38. Hashimoto, Y.; Umahara, T.; Hanyu, H.; Iwamoto, T.; Matsuoka, M. Calmodulin-like skin protein is downregulated in human cerebrospinal fluids of Alzheimer's disease patients with apolipoprotein E4; a pilot study using postmortem samples. Neurol. Res. 2017, 39, 767-772. [CrossRef]

39. Kusakari, S.; Nawa, M.; Sudo, K.; Matsuoka, M. Calmodulin-like skin protein protects against spatial learning impairment in a mouse model of Alzheimer disease. J. Neurochem. 2018, 144, 218-233. [CrossRef]

40. Hashimoto, Y.; Nawa, M.; Kurita, M.; Tokizawa, M.; Iwamatsu, A.; Matsuoka, M. Secreted calmodulin-like skin protein inhibits neuronal death in cell-based Alzheimer's disease models via the heterotrimeric Humanin receptor. Cell Death Dis. 2013,4 , e555. [CrossRef]

41. Millucci, L.; Ghezzi, L.; Bernardini, G.; Santucci, A. Conformations and biological activities of amyloid beta peptide 25-35. Curr Protein Pept. Sci. 2010, 11, 54-67. [CrossRef]

42. Pike, C.J.; Walencewicz-Wasserman, A.J.; Kosmoski, J.; Cribbs, D.H.; Glabe, C.G.; Cotman, C.W. Structure-activity analyses of beta-amyloid peptides: Contributions of the beta 25-35 region to aggregation and neurotoxicity. J. Neurochem. 1995, 64, 253-265. [CrossRef] [PubMed]

43. Clementi, M.E.; Marini, S.; Colette, M.; Orsini, F.; Giardina, B.; Misiti, F. A $\beta(31-35)$ and A $\beta(25-35)$ fragments of amyloid betaprotein induce cellular death through apoptotic signals: Role of the redox state of methionine-35. FEBS Lett. 2005, 579, 2913-2918. [CrossRef] [PubMed]

44. Frozza, R.L.; Horn, A.P.; Hoppe, J.B.; Simão, F.; Gerhardt, D.; Comiran, R.A.; Salbego, C.G. A comparative study of beta-amyloid peptides Abeta1-42 and Abeta25-35 toxicity in organotypic hippocampal slice cultures. Neurochem. Res. 2009, 34, 295-303. [CrossRef] [PubMed]

45. Peters, C.; Bascuñán, D.; Opazo, C.; Aguayo, L.G. Differential membrane toxicity of amyloid- $\beta$ fragments by pore forming mechanisms. J. Alzheimers Dis. 2016, 51, 689-699. [CrossRef]

46. D'Ezio, V.; Colasanti, M.; Persichini, T. Amyloid- $\beta$ 25-35 Induces Neurotoxicity through the Up-Regulation of Astrocytic System $\mathrm{XC}^{-}$. Antioxidants 2021, 10, 1685. [CrossRef]

47. Guo, J.-P.; Arai, T.; Miklossy, J.; McGeer, P.L. A $\beta$ and tau form soluble complexes that may promote self-aggregation of both into the insoluble forms observed in Alzheimer's disease. Proc. Natl. Acad. Sci. USA 2006, 103, 1953-1958. [CrossRef]

48. Rose, J.B.; Crews, L.; Rockenstein, E.; Adame, A.; Mante, M.; Hersh, L.B.; Gage, F.H.; Spencer, B.; Potkar, R.; Marr, R.A.; et al. Neuropeptide Y Fragments Derived from Neprilysin Processing Are Neuroprotective in a Transgenic Model of Alzheimer's Disease. J. Neurosci. 2009, 29, 1115-1125. [CrossRef]

49. Chen, X.-Y.; Du, Y.-F.; Chen, L. Neuropeptides Exert Neuroprotective Effects in Alzheimer's Disease. Front. Mol. Neurosci. 2019, 11, 493. [CrossRef]

50. Gahete, M.D.; Rubio, A.; Córdoba-Chacón, J.; Gracia-Navarro, F.; Kineman, R.D.; Avila, J.; Luque, R.M.; Castaño, J.P. Expression of the ghrelin and neurotensin systems is altered in the temporal lobe of Alzheimer's disease patients. J. Alzheimers Dis. 2010, 22, 819-828. [CrossRef]

51. Shibata, N.; Ohnuma, T.; Kuerban, B.; Komatsu, M.; Arai, H. Genetic association between ghrelin polymorphisms and Alzheimer's disease in a Japanese population. Dement. Geriatr. Cogn. Disord. 2011, 32, 178-181. [CrossRef]

52. Noble, J.W.; Almalki, R.; Roe, S.M.; Wagner, A.; Duman, R.; Atack, J.R. The X-ray structure of human calbindin-D28K: An improved model. Acta Cryst. 2018, D74, 1008-1014. [CrossRef]

53. Tao, L.; Murphy, M.E.; English, A.M. S-nitrosation of $\mathrm{Ca}(2+)$-loaded and $\mathrm{Ca}(2+)$-free recombinant calbindin $\mathrm{D}(28 \mathrm{~K})$ from human brain. Biochemistry 2002, 41, 6185-6192. [CrossRef]

54. Bauer, M.C.; Nilsson, H.; Thulin, E.; Frohm, B.; Malm, J.; Linse, S. $\mathrm{Zn}^{2+}$ binding to human calbindin $\mathrm{D}(28 \mathrm{k})$ and the role of histidine residues. Protein Sci. 2008, 17, 760-767. [CrossRef]

55. Blaszczyk, M.; Kurcinski, M.; Kouza, M.; Wieteska, L.; Debinski, A.; Kolinski, A.; Kmiecik, S. Modeling of protein-peptide interactions using the CABS-dock web server for binding site search and flexible docking. Methods 2016, 93, 72-83. [CrossRef]

56. Kurcinski, M.; Jamroz, M.; Blaszczyk, M.; Kolinski, A.; Kmiecik, S. CABS-dock web server for the flexible docking of peptides to proteins without prior knowledge of the binding site. Nucleic Acids Res. 2015, 43, W419-W424. [CrossRef] 